\title{
16. CENOZOIC BIOSTRATIGRAPHY AND PALEOECOLOGY OF SITES 403 TO 406 BASED ON THE FORAMINIFERS
}

\author{
John W. Murray, Department of Geology, University of Exeter, England
}

\begin{abstract}
Sites 403 and 404, situated on the rifted margin of Rockall Plateau, have an incomplete Tertiary succession. Late Paleocene to Eocene clastic and volcaniclastic sediments were deposited in inner shelf, brackish to marine, and mid-shelf marine environments. By middle Eocene times the water had deepened to outer shelf or upper bathyal. The upper Eocene sediments at Site 403 were deposited in upper bathyal depths. Following a long stratigraphic break to late Miocene time, sedimentation resumed in a water depth of 2200 to 2600 meters. The record from then until the present day appears to be continuous.

Sites 405 and 406 , situated south of the transform fault that bounds the southern margin of Rockall Plateau, also have an incomplete Cenozoic record. Upper Paleocene to Eocene sediments accumulated in about 1000 meters water depth. In late Miocene to Recent time the depth was 2200 to 2500 meters at Site 406 and 1800 to 3000 meters at Site 405 .

Planktonic foraminifers are rare in Paleogene sediments of Sites 403 and 404; at Sites 405 and 406 they are more common but not diverse, and short-ranging stratigraphic marker species are rare. Neogene planktonic assemblages are moderately diverse, but are temperate assemblages often lacking the stratigraphic markers so valuable in tropical zonal schemes.

Benthic foraminifers show great variety in the Paleogene successions because of the changing depositional environments. Those of the Neogene were of deep water habitat and are much more uniform; most belong to the Planulina wuellerstorfi association characteristic of the bathyal zone.
\end{abstract}

\section{INTRODUCTION AND OBJECTIVES}

Sites 403 and 404 were drilled on the rifted margin of Rockall Plateau (Figure 1). They provide a record of events during rifting and the subsequent opening of the North Atlantic between Rockall Plateau and Greenland.

Sites 405 and 406 were drilled south of the transform fault that bounds the southern margin of Rockall Plateau. They provide a record of the evolution of a transform margin.

The main objective of this study was to investigate the benthic foraminiferal assemblages in the Cenozoic sediments for the purpose of interpreting the subsidence history and the concomitant environmental changes. A further objective was to date the assemblages using the planktonic foraminifers.

\section{MATERIALS AND METHODS OF STUDY}

Shipboard scientists selected samples that represented intervals of approximately $1 \mathrm{~m} . \mathrm{y}$. (Table 1). Most of the Neogene sediments were soft and easily processed. Those that were hard were soaked in water or in a dilute solution of sodium hexametaphosphate. All samples were washed on a 240 mesh $(63 \mu \mathrm{m})$ sieve and the residue dried at room temperature. When dry, the $>120$ fraction was separated by sieving, spread on a picking tray and benthic foraminifers were picked until at least 100 had been collected; this was not possible in all cases. No attempt was made to pick assemblages of planktonic forms; instead, representative species were mounted.

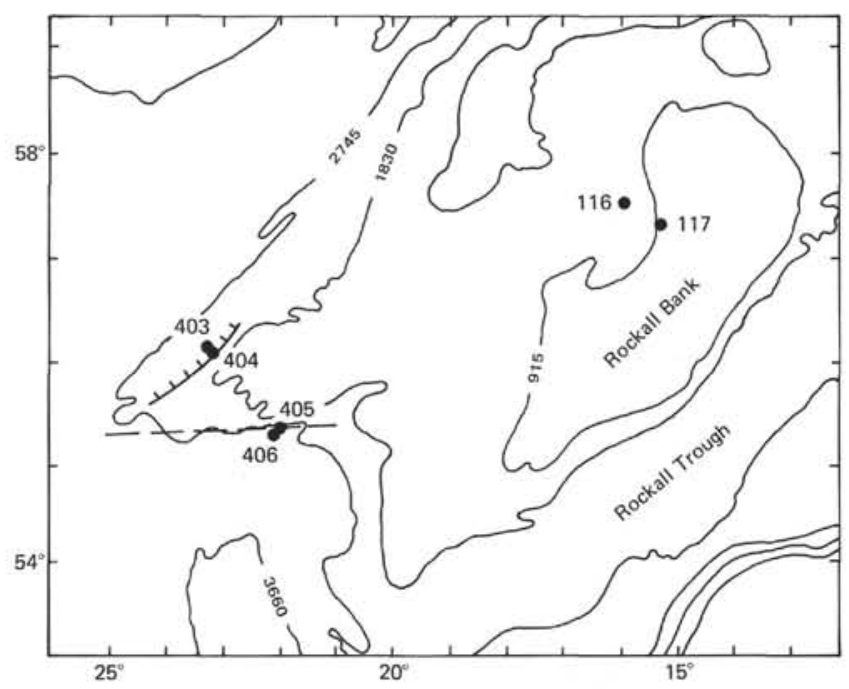

Figure 1. Location of Sites 403 to 406.

The large number of species and the limited time available for study has meant that not all species could be identified; many have been left in open nomenclature. In some figures i.e., $12,14,16,18$ and 21 to 24 ) the species plotted are those present in excess of $4 \%$ in one or more core assemblages. Those present in less than $4 \%$ overall abundance have not been plotted and are not included in the faunal reference list. 
TABLE 1

List of Samples Studied

\begin{tabular}{|c|c|c|c|}
\hline Site 403 & Site 404 & Site 405 & Site 406 \\
\hline $1-2,141-143$ & $1-2$ & $1-1,5-7$ & $1-1,30-32$ \\
\hline $3-3,11-13$ & $2, \mathrm{CC}$ & $3-2,86-88$ & $2, \mathrm{CC}$ \\
\hline $7, \mathrm{CC}$ & $3, \mathrm{CC}$ & $6-1,126-128$ & $3-1,85-87$ \\
\hline $8-6,58-80$ & $4, \mathrm{CC}$ & $7-1,38-40$ & $4-2,56-58$ \\
\hline $11, \mathrm{CC}$ & $5, \mathrm{CC}$ & $8-3,72-74$ & $5, \mathrm{CC}$ \\
\hline $16, \mathrm{CC}$ & $6, \mathrm{CC}$ & $12-4,70-74$ & $7-4,70-74$ \\
\hline $18-2,73-75$ & $\begin{array}{l}7, \mathrm{CC} \\
8-2,37-37\end{array}$ & $14-2,64-67$ & $9-1,112-116$ \\
\hline $23, \mathrm{CC}$ & $9, \mathrm{CC}$ & $16-3,108-112$ & $12, \mathrm{CC}$ \\
\hline $25, \mathrm{CC}$ & $10, \mathrm{CC}$ & $18-1,55-58$ & $20, \mathrm{CC}$ \\
\hline $26, \mathrm{CC}$ & $11, \mathrm{CC}$ & $25-1,60-63$ & $27, \mathrm{CC}$ \\
\hline $27, \mathrm{CC}$ & $16-2$ & $27, \mathrm{CC}$ & $32, \mathrm{CC}$ \\
\hline $28-1,63-70$ & $17, \mathrm{CC}$ & $28, \mathrm{CC}$ & $37-5,32-35$ \\
\hline $28, \mathrm{CC}$ & $18-1,81-87$ & $31-2,50-53$ & $42, \mathrm{CC}$ \\
\hline $29-2,30-37$ & $21-2,40-46$ & & $46-3,68-71$ \\
\hline $30-1,27-31$ & $22-2,61-68$ & & $51, \mathrm{CC}$ \\
\hline $33-1,34-40$ & $23-3,90-97$ & & \\
\hline $34-2,34-43$ & $25-1,60-66$ & & \\
\hline \multicolumn{4}{|l|}{$35-3,62-68$} \\
\hline \multicolumn{4}{|l|}{$36-2,0-7$} \\
\hline \multicolumn{4}{|l|}{$37-4,57-65$} \\
\hline \multicolumn{4}{|l|}{$38-4,38-45$} \\
\hline \multicolumn{4}{|l|}{$39-3,43-54$} \\
\hline \multicolumn{4}{|l|}{$40-3,35-42$} \\
\hline \multicolumn{4}{|l|}{$42-1,49-57$} \\
\hline \multicolumn{4}{|l|}{$42-3,37-46$} \\
\hline $43-1,81-90$ & & & \\
\hline
\end{tabular}

Note: Sequence of numbers is core-section-position; $\mathrm{CC}=$ core catcher; in the text samples are generally referred to by site and core number only.

\section{BIOSTRATIGRAPHY AND PLANKTONIC FORAMINIFERS}

\section{Paleogene}

Paleogene sediments were cored in the North Atlantic on DSDP Leg 12 and a provisional multiple zonation was proposed by Berggren (1972b). It has not been possible, however, to apply his zonation here because many of the diagnostic species have not been recorded from Sites 403 to 406 .

Identification of species has been made with reference to Stainforth et al. (1975), Postuma (1971), and Loeblich et al. (1957). The Paleogene assemblages are of low diversity, and few in numbers and size. Stratigraphically useful forms are uncommon and the resultant dates are imprecise. There is however, reasonable agreement between the dates shown herein and those determined by the shipboard scientists.

\section{Site 403 (Figure 2)}

Planktonic foraminifers are rare in Cores 42 to 34 and are mainly of the Globigerina linaperta group. Because Core 29 contains Globorotalia esnaensis and $G$. pentacamerata, of early Eocene (P 8) age, the sediments in Cores 42 to 34 are considered to be late Paleocene to early Eocene (P5-8) age.

Cores 28, 27, and 26 are dated as mid Eocene (P10-12) on the presence of Globorotalia bullbrooki which occurs together with the Globigerina linaperta group and Pseudohastigerina wilcoxensis. However, Core 28 may be of early Eocene age (see the section on Paleogene benthic forms). Core 25 yielded Catapsydrax dissimilis and Globigerapsis index which give an overlapping range of middle Eocene (P13) to lower Oligocene (P18). Berggren (1972b) consi-

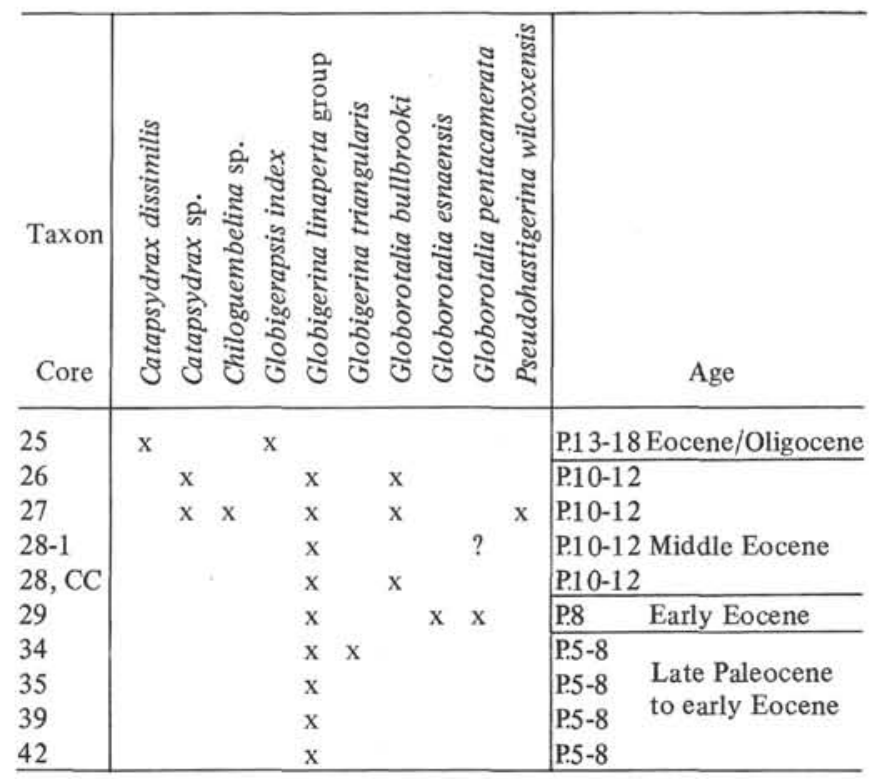

Figure 2. Occurrence of planktonic foraminifers in the Paleogene at Site 403.

dered that $G$. index might be a useful upper Eocene marker in high latitudes. He also found $C$. dissimilis to be a dominant form in Oligocene assemblages. Thus, this assemblage may be indicative of the Eocene/Oligocene boundary, and if so, the succession between Cores 26 and 25 is either condensed or else contains a hiatus.

\section{Site 404 (Figure 3)}

Cores 23,22 , and 18 contain a sparse planktonic assemblage of the Globigerina linaperta group assigned to the upper Paleocene-lower Eocene (P5-8).

Cores 17, 16, 11 and 9 contain Globigerina linaperta group together with Pseudohastigerina wilcoxensis, Globorotalia esnaensis, and Globigerina triangularis (which may be a variant of the $G$. linaperta group). This part of the succession is of latest Paleocene or early Eocene age (P5-8). Truncorotaloides rohri, of middle Eocene age, appears in Cores 8 and 7.

\section{Site 405 (Figure 4)}

The lower part of the succession is of late Paleocene to early Eocene (P5-8) age, based on the presence of the Globigerina linaperta group with one or more of Globigerina triangularis, Globorotalia esnaensis, or Pseudohastigerina wilcoxensis (Cores $31,28,27,25,18,16$, and 14). Core 12 contains only $G$. linaperta. Core 8 yielded a somewhat different assemblage consisting of Globigerina boweri, Globorotalia pentacamerata, and Pseudohastigerina wilcoxensis; it is early to middle Eocene (P8-12) in age.

\section{Site 406 (Figure 5)}

Cores 51 and 46 contain an assemblage typical of the Globorotalia pentacamerata Zone (P9) (after Stainforth et al., 1975, p. 68), except that Core 46 contains, in addition, Globigerinita unicava primitiva (range P14-18). The latter species is present with Globigerapsis index in Core 42, representing a mid to late Eocene age. Chiloguembelina sp., Catapsydrax dissimilis, and $G$. index are present in Core 37 


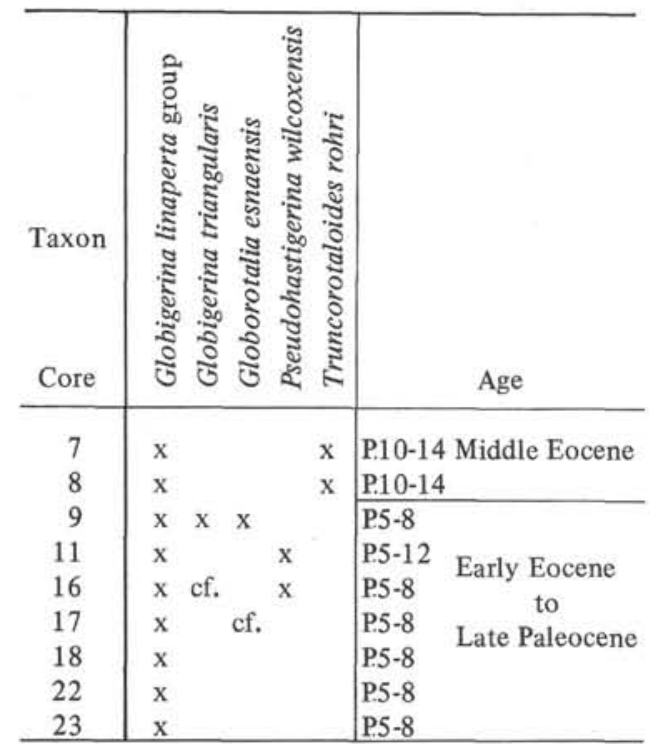

Figure 3. Occurrence of planktonic foraminifers in the Paleogene at Site 404.

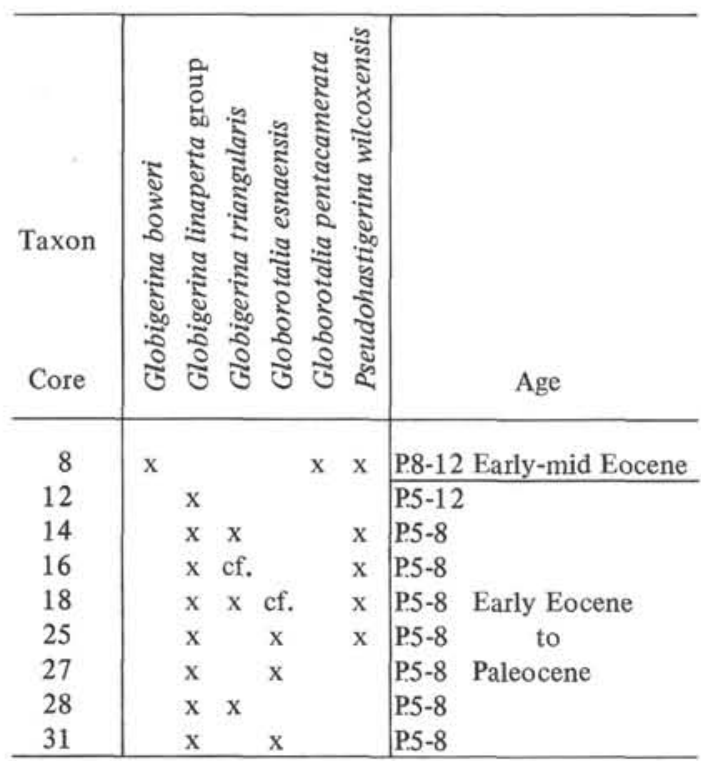

Figure 4. Occurrence of planktonic foraminifers in the Paleogene at Site 405.

again indicating middle to late Eocene dating. Cores 32 and 27 contain a sparse fauna of Catapsydrax dissimilis and Globigerina venezuelana of late Oligocene to early Miocene age.

\section{Discussion}

The Paleocene-early Eocene assemblages recorded by Berggren (1972a,b) from Site 117 are minimally diverse, small-sized forms similar to those reported here. Oligocene assemblages from Sites 116 and 117 were somewhat more diverse and include several species not seen in the few Oligocene samples discussed here (Globigerinita pera, Globigerina ampliapertura, Globorotalia spp.). It is clear that conditions for the preservation of the planktonic as-

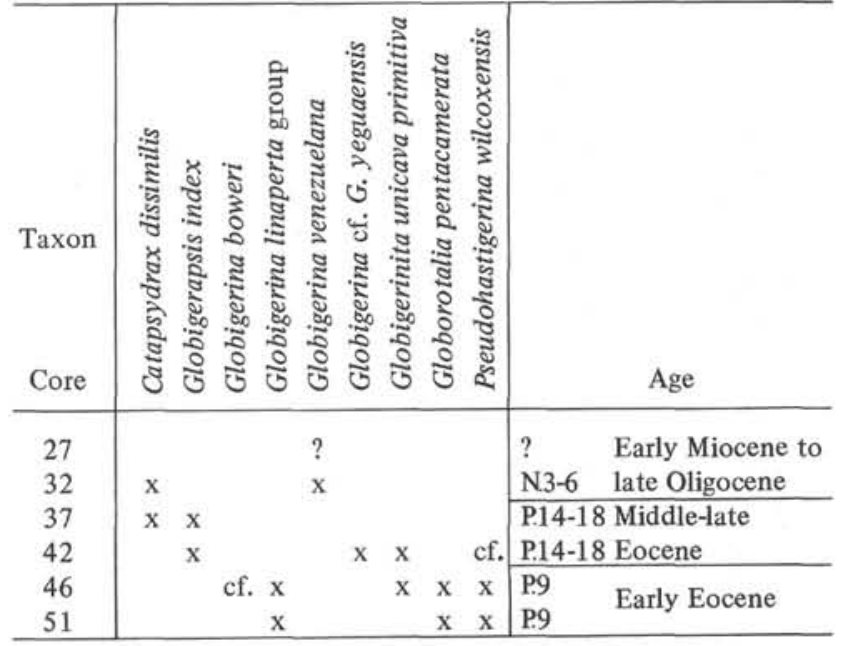

Figure 5. Occurrence of planktonic foraminifers in the Paleogene at Site 406.

semblages were poor at Sites 405 and 406 and this may account in part for the low diversity of the assemblages.

\section{Neogene}

From a study of DSDP Sites 111 to 119 Berggren (1972b) set up a series of planktonic foraminiferal zones for the North Atlantic and showed their probable correlation with the tropical zonation of Blow (1969). Descriptions of the zones recognized at Site 116 (Hatton-Rockall Basin) were given by Poore and Berggren (1975). They did not recognize a zone equivalent to N20 in the North Atlantic. Five of their zones are interval zones and two are lineage-segment zones.

In this study it has been found most convenient to use, where appropriate, the ranges given by Blow (1969). Poore and Berggren (1975) have recorded Globorotalia puncticulata from sediments considered to be of N18 age (cf. top N19 as the lower limit given by Blow). They also noted the change in coiling of Neogloboquadrina atlantica from right to left at approximately the transition from Miocene to Pliocene time. The ranges quoted by these authors for DSDP Site 116 occurrences of Globorotalia crassaformis and $G$. inflata are shorter than those quoted by Blow (1969) but the latter has been followed.

In most cases shipboard scientists already had given a provisional age to the samples studied. Not all species recorded onboard were found when the author examined the material and, of course, additional species were found. Globorotalia margaritae, for example, was recorded by shipboard scientists from many of the upper Miocene samples, but the author found no specimens with the characteristic concavity of the umbilical side. In spite of these differences there is general agreement about the age designations of most of the cores. The Neogene assemblages show a marked contrast with those from the Paleogene, being diverse, abundant, and often of large size.

\section{Site 403 (Figure 6)}

The oldest Neogene sediments are of late Miocene age $(G$. conomiozea Zone, =N17) in Cores 23, 18, and 16. Stratigraphically important species include Globigerina apertura, 


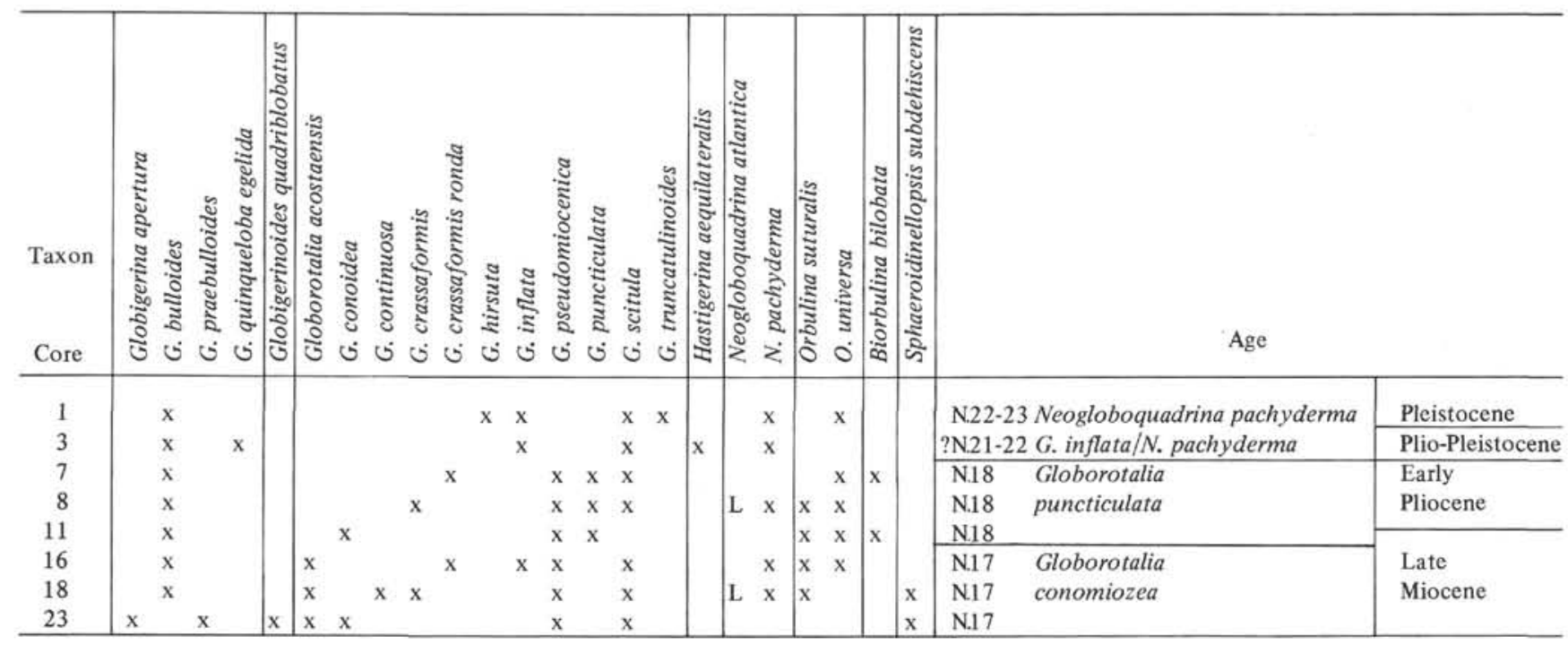

Figure 6. Occurrence of planktonic foraminifers in the Neogene at Site 403.

$G$. praebulloides, Globorotalia conoidea, and $G$. pseudomiocenica. Neogloboquadrina atlantica (left coiling) is present in Core 18 which suggests that this level is high in the $G$. conomiozea Zone.

Cores 11,8 and 7 contain Globorotalia puncticulata, which indicates the lower part of the $G$. puncticulata Zone (N18, early Pliocene).

Core 3 contains much clayey and silty clastic material and the planktonic fauna is characterized by abundant Neogloboquadrina pachyderma. Shipboard scientists recorded Globorotalia tosaensis but this was not confirmed by the author. The age would be N21-22 if this species is present. The topmost sample, Core 1, can be assigned to N22-23, Neogloboquadrina pachyderma Zone, on the presence of Globorotalia truncatulinoides.

\section{Site 404 (Figure 7)}

Cores 6 and 5 are dated as N16-17 (N. acostaensis ZoneG. conomiozea Zone, late Miocene), based on the overlap of Globorotalia continuosa, G. merotumida, G. plesiotumida, and $G$. pseudomiocenica. Core 4 is of $\mathrm{N} 17$ age $(G$. conomiozea Zone) based on Globigerina praebulloides and Globorotalia conoides. Core 3 contains G. plesiotumida (N17-18).

A number of new forms appear in Core 2 (Globorotalia crassaformis, G. hirsuta, G. inflata, Neogloboquadrina pachyderma) and, in addition, forms transitional between. Globorotalia tosaensis and $G$. truncatulinoides. This suggests the level of the Pliocene/Pleistocene boundary, N21-22, Globorotalia inflata/Neogloboquadrina pachyderma zones. Core 1 contains a modern assemblage of the $N$. pachyderma Zone (N22-23).

\section{Site 405 (Figure 8)}

Cores 7 and 6 contain Globorotalia pseudomiocenica of late Miocene age (N16-18, G. acostaensis-G. conomiozea zones). Core 6 also contains Neogloboquadrina atlantica (left coiling) which suggests early Pliocene although Globorotalia puncticulata is absent. This level is therefore believed to be N18 or lowest $G$. puncticulata Zone.

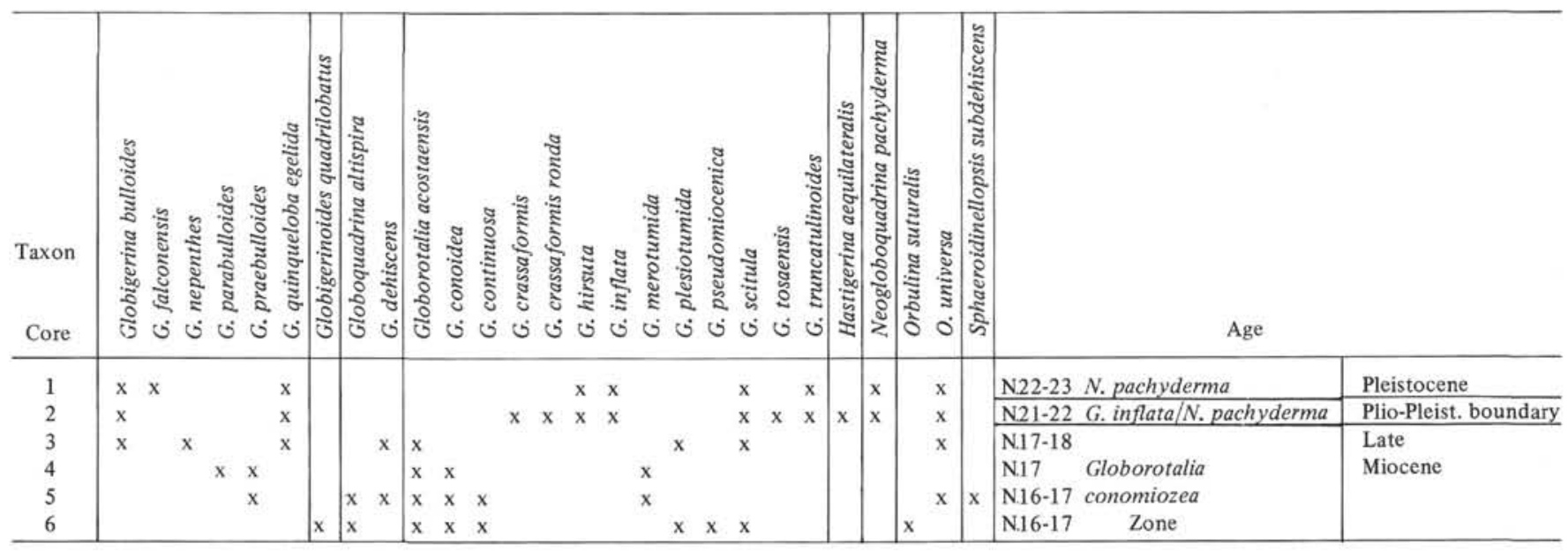

Figure 7. Occurrence of planktonic foraminifers in the Neogene at Site 404. 


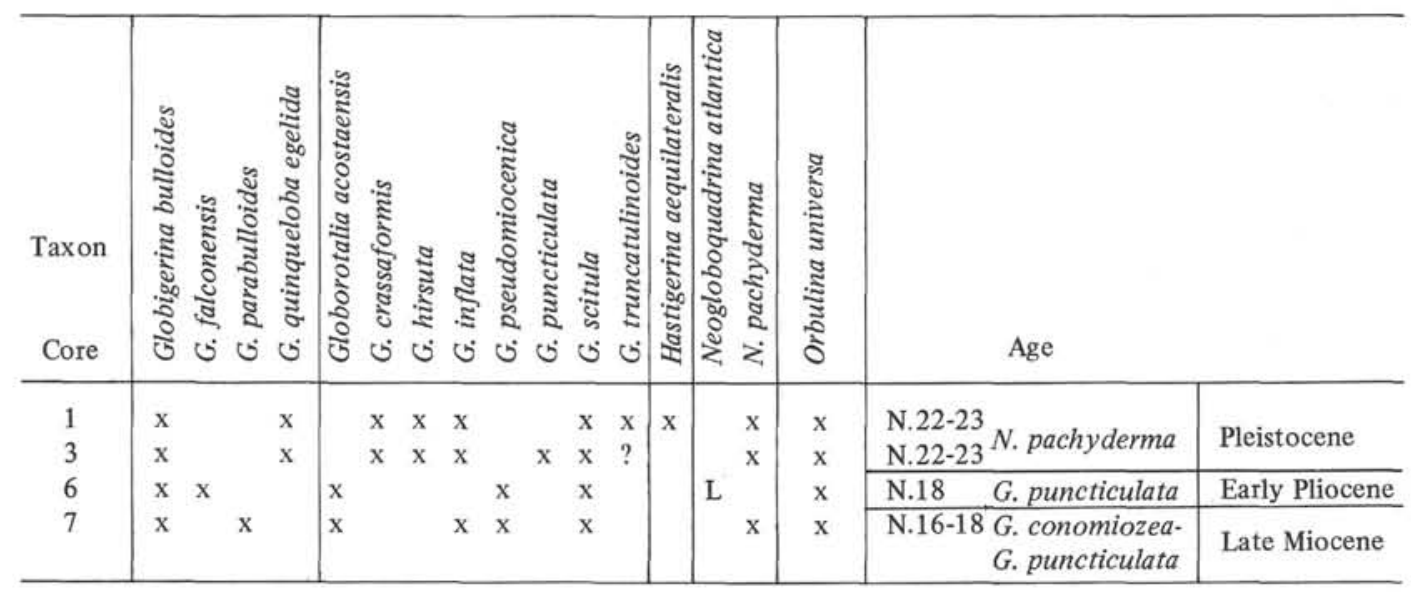

Figure 8. Occurrence of planktonic foraminifers in the Neogene at Site 405.

A major faunal change takes place above this as cores 3 and 1 contain a modern assemblage of the Pleistocene (N2223. Neogloboquadrina pachyderma Zone). There is thus a hiatus between Cores 6 and 3 representing most of the Pliocene.

\section{Site 406 (Figure 9)}

The lower-middle Miocene boundary is encountered in Core 20 which contains the stratigraphically restricted species Globigerinoides sicanicus and Praeorbulina glomerosa curcularis. The absence of Orbulina suturalis and $O$. universa may indicate that this is early Miocene in age (N8, Praeorbulina spp. Zone).

Cores 12, 9, 7, and 5 yielded assemblages containing Globorotalia acostaensis, $G$. conoides, and $G$. merotumida or G. pseudomiocenica; all are of late Miocene age (N17, Globorotalia conomiozea Zone). Core 4 has fewer biostratigraphically important species and is considered to be late Miocene to early Pliocene in age (N17-18), G. conomiozea to $G$. puncticulata zones.

Core 3 contains left-coiling Neogloboquadrina atlantica, but lacks Globorotalia inflata and is dated as late Pliocene
(N19-21 Globorotalia crassaformis Zone). Cores 2 and 1 are assigned to the Pleistocene.

Shipboard scientists recorded a hiatus between Cores 20 (early Miocene) and 19 (late Miocene); in this study it is apparent between Cores 20 and 12 . The shipboard age determination of Core 3 was N19 (based on Globortalia cf. cibaoensis) whereas here it is considered to be $\mathrm{N} 22$ based on the presence of $G$. hirsuta. If this is correct there is a hiatus between Cores 4 and 3 .

\section{Discussion}

Early Miocene sediments are rare at the four sites under discussion and only at Site 406 (Core 20) were they positively identified. The assemblage includes Globigerina praebulloides, Globigerinoides quadrilobatus immaturis, $G$. sicanicus, Globorotalia scitula, G. scitula praescitula, G. siakensis, and Praeorbulina glomerosa. This compares well with the Praeorbulina Zone of Berggren (1972b) and Poore and Berggren (1975).

Middle Miocene sediments were not encountered at Sites 403 to 406 .

Late Miocene sediments are present at all four sites. Planktonic foraminifers are abundant and characteristic

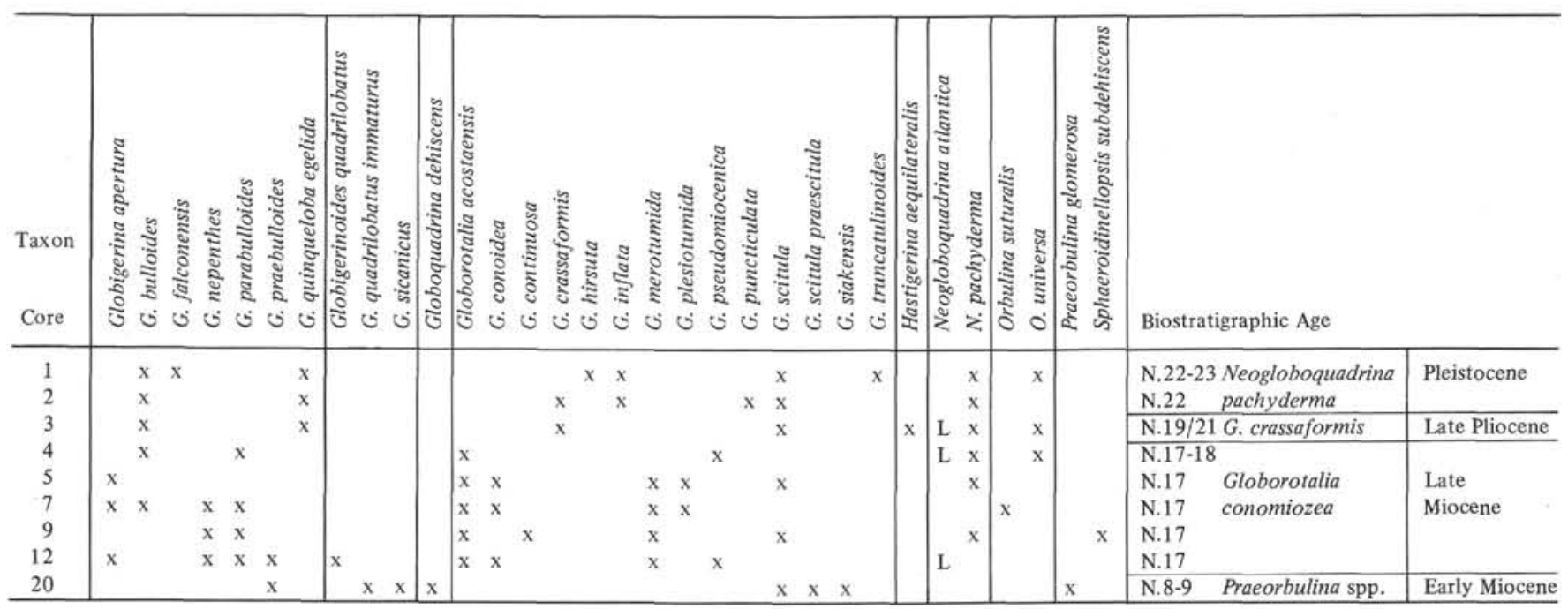

Figure 9. Occurrence of planktonic foraminifers in the Neogene at Site 406. 
species include Globorotalia acostaensis, $G$. conoides, $G$. merotumida, G. plesiotumida, G. pseudomiocenica, and Orbulina suturalis.

Early Pliocene sediments are best developed at Site 403 where Globorotalia puncticulata is present with $G$. pseudomiocenica, G. crassaformis, and Neogloboquadrina atlantica. Late Pliocene sediments were possibly encountered at Site 404 (Core 2) where forms transitional between Globorotalia tosaensis and $G$. truncatulinoides are present.

The Pleistocene to Recent assemblages are composed of Globigerina bulloides, G. quinqueloba egelida, Globorotalia hirsuta, G. inflata, G. scitula, G. truncatulinoides, Neogloboquadrina pachyderma, and Orbulina universa. This is a typical temperate North Atlantic assemblage.

These assemblages are similar to those reported from the North Atlantic by Berggren (1972b) and Poore and Berggren (1975), but the Pliocene sediments are far less rich in $N$. atlantica than the above authors report from their study area.

\section{BOLBOFORMA}

Daniels and Spiegler (1974) described a new genus of incertae sedis, Bolboforma, from the Oligocene and Miocene of northwest Germany. The 11 species had distinct stratigraphic ranges and some of them have since been recorded from the Miocene of DSDP Site 35 off Antarctica (Rögl, 1976).

The occurrence of this genus at Sites 403, 404, and 406 (absent from 405) is shown in Figure 10. It occurs mainly in Zone N17, possibly ranging from N16-N18 where dating of samples cannot be to an individual $\mathrm{N}$-zone. This group of species may be important useful biostratigraphic markers.

\section{CRITERIA FOR THE PALEOECOLOGICAL INTERPRETATION OF THE BENTHIC ASSEMBLAGES}

Paleoecological interpretation of the fossil benthic foraminiferal assemblages is not only dependent upon comparison with modern assemblages, but is also complicated by the faunal differences between Tertiary and modern assemblages.

In the past few years two reviews of the ecology and distribution of modern benthic assemblages have been published. Murray (1973) discussed living assemblages from all the major environments whereas Boltovskoy and Wright (1976) summarized the data on living, dead, and total assemblages. The relationships between living and dead assemblages and the reliability of the fossil record have been

Genus Bolboforma

\begin{tabular}{|c|c|c|c|c|c|c|c|c|c|c|}
\hline \multicolumn{2}{|c|}{ Site } & \multicolumn{2}{|c|}{403} & \multicolumn{4}{|c|}{404} & \multicolumn{3}{|c|}{406} \\
\hline Species & Core & 18 & 23 & 3 & 4 & 5 & 6 & 5 & 7 & 9 \\
\hline \multicolumn{2}{|c|}{$\begin{array}{l}\text { aculeata } \\
\text { clodiusi } \\
\text { intermedia } \\
\text { laevis } \\
\text { metzmacheri } \\
\text { spiralis }\end{array}$} & $\mathrm{x}$ & $\mathrm{x}$ & $\begin{array}{l}x \\
x\end{array}$ & $\begin{array}{l}x \\
x\end{array}$ & $\begin{array}{l}x \\
x\end{array}$ & $\begin{array}{l}x \\
x \\
x \\
x\end{array}$ & $\begin{array}{l}x \\
x\end{array}$ & $\mathrm{x}$ & $\mathrm{x}$ \\
\hline
\end{tabular}

Figure 10. Occurrence of species of Bolboforma. discussed for shelf and marginal marine assemblages by Murray (1976a). In addition, a method has been proposed for the paleoecological interpretation of fossil assemblages (Murray, 1973).

The interpreted environments of life of the Cenozoic assemblages discussed here range from shallow continental shelf to deep bathyal. The criteria for interpretation and the data used for comparison of shelf assemblages are all adequately discussed in the references cited above. This is not true of bathyal assemblages so a brief resumé is given below.

Many studies of modern benthic foraminifers have concentrated on distribution changes with increasing water depth. However, changes in depth are always accompanied by changes in other important environmental parameters such as salinity, temperature stratification, dissolved oxygen, relative solubility of carbonates, etc. (Murray, 1973). Thus, the interpretation of distribution changes cannot be made solely with reference to changes in depth. There is ample evidence of this because individual species show different depth distributions in different geographic regions.

Bandy and Chierici (1966) highlighted the problem in their comparison of the depth-temperature distribution of bathyal benthic foraminifers from the Mediterranean and from off the coast of California. They subdivided the species into isobathyal and heterobathyal groups. The former showed similar depth ranges in the two geographic areas whereas the latter group did not. Thus, it should not be expected that there is a worldwide pattern of foraminiferal depth distributions based on the same associations of species. It is more realistic to consider that the depth distributions will be different from region to region although some of the general features of assemblages and associations may be applicable over a wider area.

In two recent reviews of foraminifer distributions the following generalizations have been made (Murray, 1973; Boltovskoy and Wright, 1976): (1) forms with calcareous tests dominate the bathyal zone although they are known to live down to $>6000$ meters; (2) agglutinated species characterize the abyssal and hadal zones; (3) many of the species are cosmopolitan; (4) diversity is high in the deep sea because of environmental stability.

To this list may be added the observation by Belyaev (1966, p. 41) that foraminifers are more eurybathic than most metazoan groups. However, it was pointed out that two problems beset the study of benthic foraminifers in the deep sea. First, slow sedimentation gives rise to condensed deposits in which dead tests may be transported, especially downslope, thereby extending the apparent depth range.

Another generalization is the correlation of the form and structure of foraminifers with environment (Brady, 1964).

No studies of the bathymetric distribution of foraminifers in the area of Rockall Bank have yet been published. The geographically closest studies are those of Caralp, Lamy, and Pujos (1970) and Pujos-Lamy (1973a) in the Bay of Biscay, and Seiler (1975) off Portugal; in addition, there are records from the North Atlantic (Brady, 1884; and Cushman, 1918-1931). With the exception of the study by Seiler, all of these records are of dead forms only.

Both the Portuguese offshore area and the Bay of Biscay are under the influence of the Mediterranean outflow current 
which flows along the upper slope in a northerly direction. This water mass is characterized by a salinity $>36 \%$, temperature $>1^{\prime} 1^{\circ} \mathrm{C}$, and relatively low dissolved oxygen $(<4.5$ $\mathrm{ml} / 1$ ) near Cape Vicente although these values undergo change with passage north. The salinity maximum is at a depth of 1100-1300 meters off Cape Vicente and $\sim 1000$ meters off Cape Finistere.

Seiler (1975) records the following six genera as common: Bolivina (including Brizalina), Bulimina, Cassidulina (including Globocassidulina), Epistominella, Trifarina, and Uvigerina. In the Bay of Biscay, genera common in the depth range 180 to 1700 meters are (Caralp et al., 1970) Ehrenbergina, Trifarina, and Uvigerina; from 1700 to 2500 meters Loxostomum, Bulimina, and Uvigerina; and from 2500 to 3000 meters Pullenia, Planulina, Eponides, Epistominella, and Melonis (given as Nonion pompilioides).

Pujos-Lamy (1972) notes that in the upper bathyal zone (180-1700 m) agglutinated foraminifers (Textulariina) form 1-2 per cent of the total assemblage, in the lower bathyal zone $(1700-4000 \mathrm{~m}) 5-24$ per cent, at depths greater than 4000 meters $>30$ per cent.

Diversity is an important measure of assemblages and the $\alpha$ index of Fisher et al. (1942; and see Murray, 1973) has been used here. Seiler (1975) gives data for the living assemblages off Portugal whereas Caralp et al. (1970) give data for the total assemblages of the Bay of Biscay. Their results are summarized in Figure 11, using the bathymetric divisions of Pujos-Lamy (1973a). The majority of the assemblages studied come from the epibathyal zone, and only one has been studied from the infrabathyal zone so this may account for the different ranges of variability. In all these depth zones the values of $\alpha$ are generally $>10$ whereas on continental shelves such high values are not common.

Walton (1964) introduced the concept of faunal dominance, the highest percentage occurrence of any one species in each assemblage. Data from Seiler (1975) and Caralp et al.

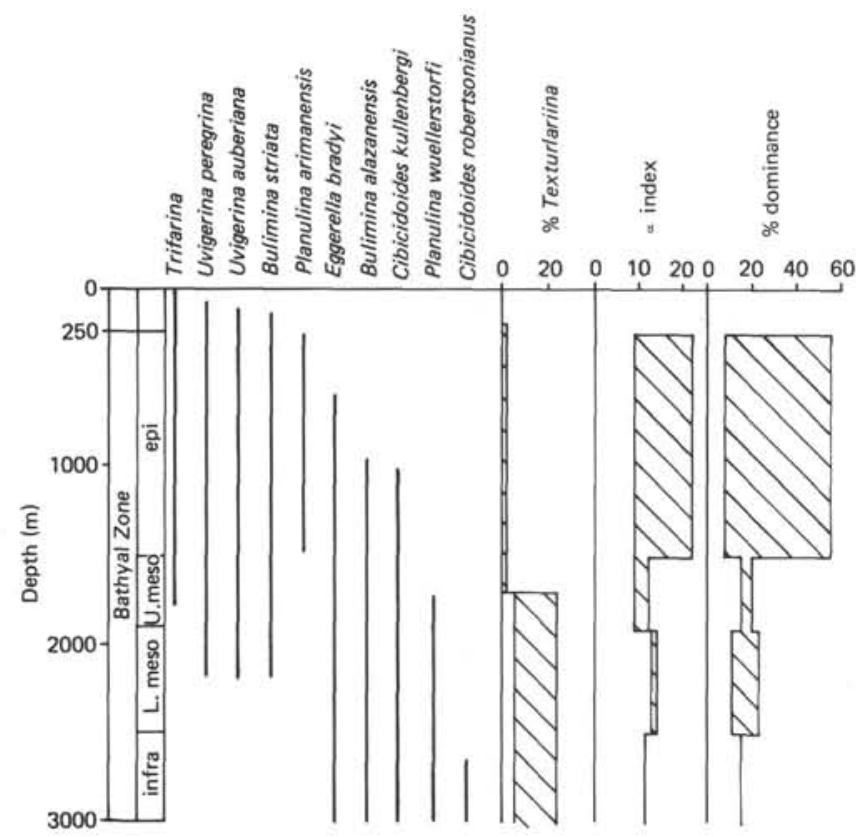

Figure 11. Summary of modern benthic foraminifers depth distribution off Portugal and the Bay of Biscay. have been summarized in Figure 11. The problem of sampling is the same here as for diversity. In general one would expect per cent faunal dominance to be low when the diversity is high and vice versa. It is therefore surprising that in the epibathyal zone faunal dominance ranges from 8 to 55 per cent. Walton $(1964$, p. 217) stated that all faunas whose dominant species constitute over 35 per cent of the entire fauna occur shallower than 10 fathoms! Clearly this does not apply in this case.

Along the European seaboard the majority of benthic species shows no restricted depth distribution. Those that do have been plotted on Figure 11 (data from Brady, 1884; Cushman, 1918-1931; Caralp et al., 1970; Pujos-Lamy, 1973a; Murray, 1971).

Brouwer (1973) introduced the concept of the Planulina wuellerstorfi fauna which he believes to be present throughout the Atlantic Ocean in the depth range 1350 to 5084 meters. This fauna is recognized on the co-occurrence of any of the following species which together make up $>5$ per cent of the total fauna: Eggerella bradyi, Pullenia bulloides, Globocassidulina subglobosa, Epistominella exigua, Oridorsalis umbonatus, Nuttallides umboniferus, Planulina wuellerstorfi, and Melonis pompilioides. This is a useful concept and it has particular application to the interpretation of the Neogene assemblages.

However, Streeter (1973) demonstrated that variations in the specific composition of deep water benthic assemblages in the North Atlantic could be correlated with the water masses more readily than with depth alone. He recognized three main assemblages characterized by ?Epistominella umbonifera ( $>4000 \mathrm{~m}<2.0^{\circ} \mathrm{C}$ potential temperature), Cibicides $(=$ Planulina $)$ wuellerstorfi - Epistominella exigua (4000-2500 $\mathrm{m} 2.0-3.0^{\circ} \mathrm{C}$ potential temperature), and Nummoloculina irregularis - Cibicides kullenbergi $(<2500 \mathrm{~m}$ $3.0-4.0^{\circ} \mathrm{C}$ potential temperature). In addition he found that Uvigerina hollicki is dominant at a depth of $\sim 1200$ meters and a temperature of about $4^{\circ} \mathrm{C}$. Both Streeter (1973) and Schnitker (1974) have used changes in benthic foraminifer assemblages in late glacial sediments to infer changes in bottom water mass circulation. Lack of detailed data on species distributions in both these papers has meant that it is difficult to apply the results to the interpretation of Cores 403 to 406 .

The ratio of planktonic to benthic foraminifers is commonly used as a guide to water depth. In a recent review of data from modern sediments Murray (1976b) demonstrated that this ratio varies not only with water depth, but also with distance from the source of supply of planktonic tests. When planktonic forms are transported from an oceanic water mass onto and across a continental shelf, where the environment is not favorable for the existence of these forms, the tests become progressively smaller the further the distance from source. It is therefore worth measuring the size of the largest planktonic individual in each assemblage. These have been plotted on Figures 12 to 24 .

\section{BENTHIC FORAMINIFERAL PALEOECOLOGY Paleogene}

\section{Site 403 (Figures 12, 13)}

The deepest fossiliferous Core is 42 (Section 1, $49-57 \mathrm{~cm}$ ). The assemblage has a high diversity $(\propto=12)$ and is domi- 


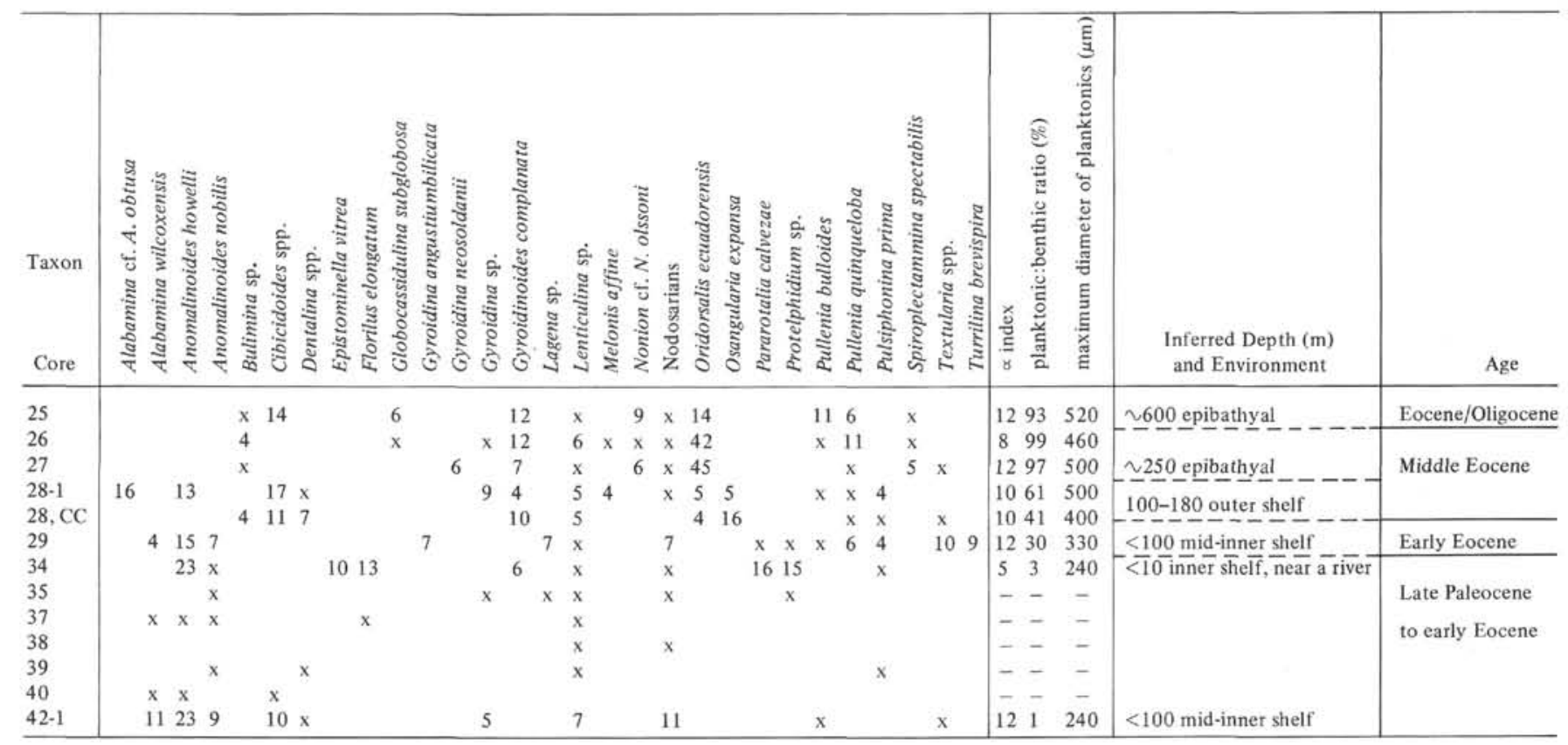

Figure 12. Occurrence of benthic foraminifers $>4 \%$ ) in the Paleogene at Site 403 (values in $\%, x=<4 \%$; Cores 30, 33, 36, 42,43 , and 44 were barren).

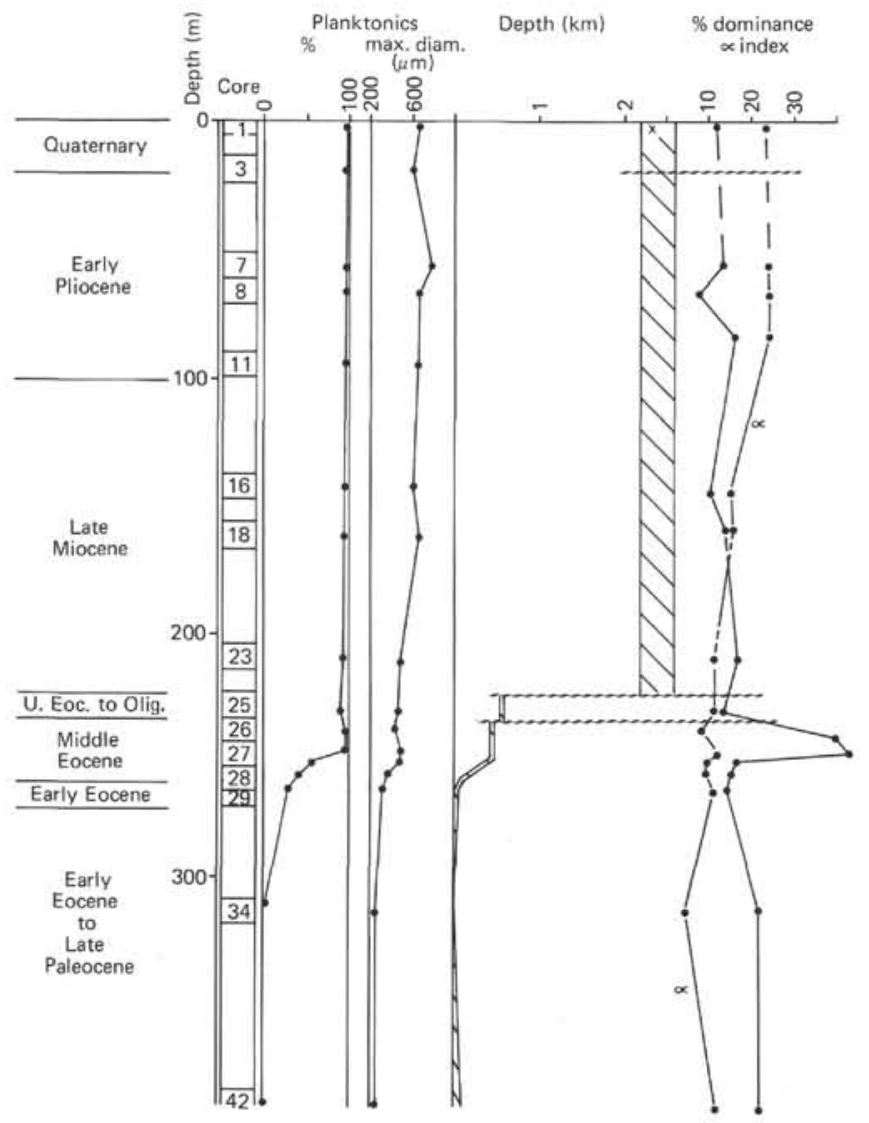

Figure 13. Summary log of Site $403(R=$ rare foraminifers). nated by Anomalinoides howelli, Alabamina wilcoxensis, nodosarians, and Cibicidoides spp. From its high diversity it is interpreted as normal marine. The species suggest mid to inner shelf and this is supported by the low planktonicbenthic ratio and the small size of the planktonic individuals.

Poor faunas were recovered from Core 42 to Core 34 and it is not possible to determine the paleoecology.

Core 34 yielded a distinctive assemblage of low diversity $(\propto=5)$. The dominant species include Anomalinoides howelli, Pararotalia calvezae, Protelphidium sp., Florilus elongatum, and Epistominella vitrea. The latter species is a dominant form in the deltaic marine environments of the Mississippi and Ebro deltas (see Murray, 1973, p. 77, 80, for a summary). It lives in waters of normal salinity, at a depth of $>10$ meters in turbid waters. Protelphidium lives in brackish to marine waters especially in estuaries and lagoons. Thus this assemblage is thought to represent shallow inner shelf close to a river.

The next fossiliferous level (Core 29) yielded an assemblage dominated by Anomalinoides howelli with several common accessory species (see Figure 12). The diversity is high and the proportion and size of the planktonic forms shows an increase over those below. These features suggest a deepening of the water to $<100$ meters, mid to inner shelf.

A significant faunal change takes place above this level. The dominant forms in Cores 28, CC and 28-1 include Cibicidoides spp., Gyroidina sp., Gyroidinoides complanata, and Osangularia expansa; Oridorsalis ecuadorensis also appears. The planktonic-benthic ratio increases to 61 per cent and the planktonic size increases to $500 \mu \mathrm{m}$. This evidence points to an outer shelf environment, with a depth of 100 to 180 meters. The assemblage includes Pulsiphonina 
prima as well as $O$. expansa and $A$. noblis, which suggest an early Eocene age (P9). This would not conflict with the evidence from the planktonic foraminifers as the known range of Globorotalia bullbrooki is P9-13.

Cores 27 and 26 have similar assemblages dominated by Oridorsalis ecuadorensis with common accessory Gyroidinoides complanata and less common Gyroidina neosoldanii, Lenticulina sp., Nonion cf. N. olssoni, Pullenia quinqueloba, and Spiroplectammina spectabilis. Rare species include Nuttallides truempyi, Pleurostomella sp., and Cyclammina sp. The assemblage is thought to represent the upper part of the epibathyal zone $(\sim 250 \mathrm{~m})$. The planktonic-benthic ratios are high $(97-99 \%)$ and the maximum size of the planktonic individuals is $460-500 \mu \mathrm{m}$.

There is probably a hiatus between Cores 26 and 25 . The assemblages are, however, similar in several respects and differ mainly in the lesser abundance of Oridorsalis ecuadorensis in Core 25. New rare species include Bulimina striata, Eggerella bradyi, Epistominella pulchella, and Cassidulina laevigata. The upper depth limit of $E$. bradyi is $\sim 600$ meters and this may represent the depth of deposition of this assemblage.

\section{Site 404 (Figures 14 and 15)}

The oldest core (23) yielded a sparse assemblage dominated by Florilus elongatum and Protelphidium sp. Core 22 has a richer assemblage in which these two dominant species are joined by Anomalinoides howelli and Elphidium hiltermanni. The assemblage in Core 21 is similar but lacks Florilus elongatum and Protelphidium sp. forms 72 per cent of the total. In these cores planktonic foraminifers are rare. The $\alpha$ index is low, especially in Core 21. The assemblages are indicative of shallow, marginal marine environments which, in the case of Core 21 , was probably brackish.

The rest of the late Paleocene to early Eocene assemblages are dominated by Anomalinoides howelli. The morphology of this species suggests that it lived clinging to a firm substrate such as shells or seaweeds. Common accessory species are Alabamina wilcoxensis and Osangularia expansa. Other accessory species which are sometimes common include Globocassidulina subglobosa, Gyroidina angustiumbilicata, Lenticulina sp., and Pulsiphonina prima. With the probable exception of Anomalinoides howelli these species are muddy substrate forms, typical of continental shelves.

The diversity values are in the range $\alpha 9$ to 12 which suggests a fully marine environment. The per cent faunal dominance is high (33-54\%, mainly Anomalinoides howelli). The planktonic:benthic ratio ranges from 7 per cent in Core 18 to 80 per cent in Core 16 and intermediate values in Cores 11 and 9 (50 and 58\%). The planktonic individuals may have undergone some solution as juveniles are not common, but even the largest individuals only range from 320 to $380 \mu \mathrm{m}$. The small size and low to moderate abundance of planktonic individuals suggest a continental shelf environment some distance away from the open ocean (see Murray, 1976b). The assemblages of Cores 18 and 17 are of inner shelf type with a depth of $<75$ meters. Cores 16 to 9 have assemblages indicative of middle to outer shelf depths $(75-150 \mathrm{~m})$. The middle Eocene assemblages (Cores 8 and 7) are likewise dominated by Anomalinoides howelli. Many of the other benthic species are different from those of the early Eocene. The planktonic:benthic ratio is 66 to 87 per cent and the planktonic forms are marginally larger (maximum diameter $320-400 \mu \mathrm{m})$. Nevertheless, this is still a shelf assemblage, probably outer shelf, in the depth range 100 to 180 meters.

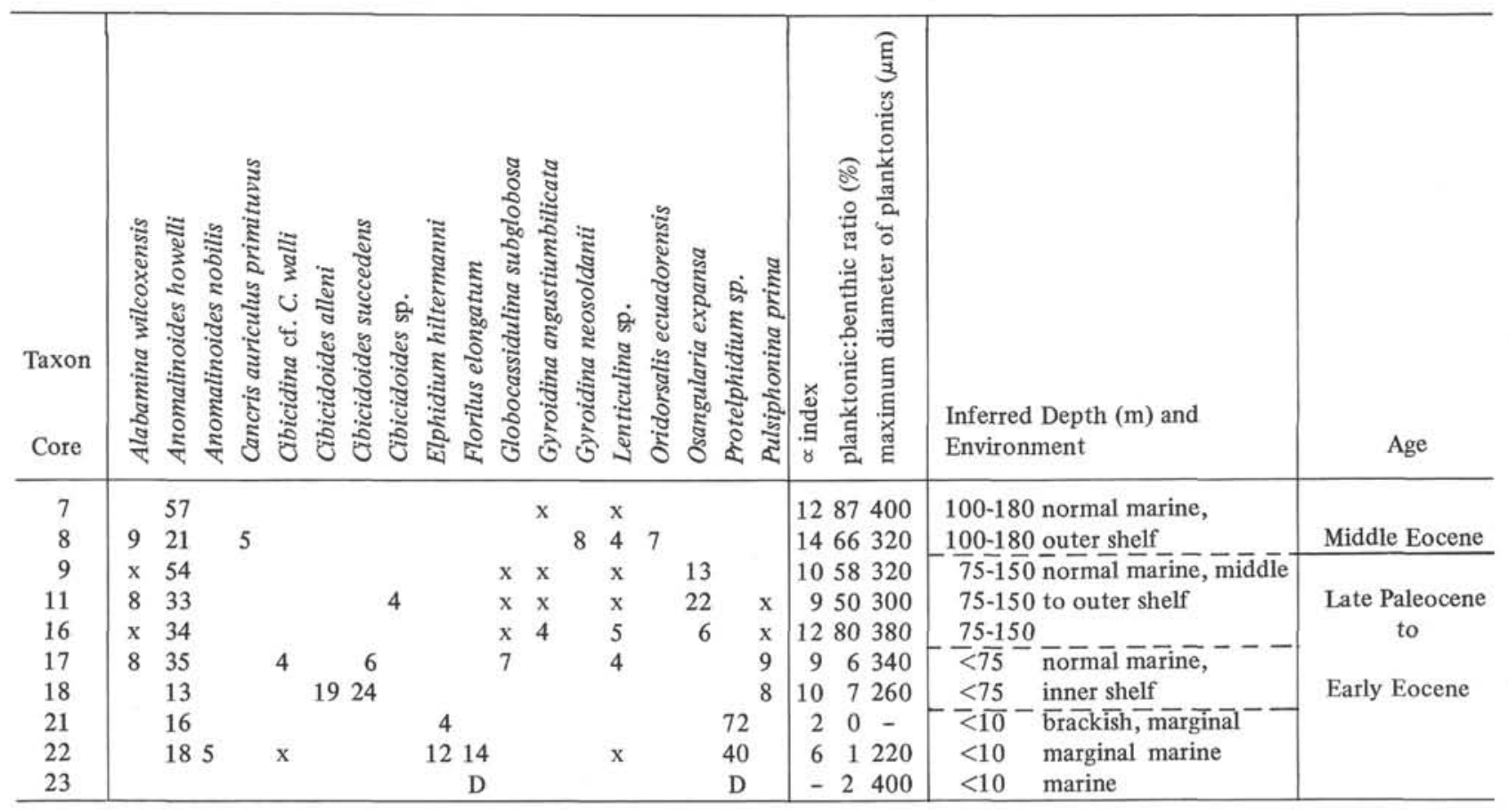

Figure 14. Occurrence of benthic foraminifers $>4 \%$ ) in the Paleogene at Site 404 (values in $\%, x=<4 \%$; Core 23 yielded a small assemblage, $D=$ dominant species). 


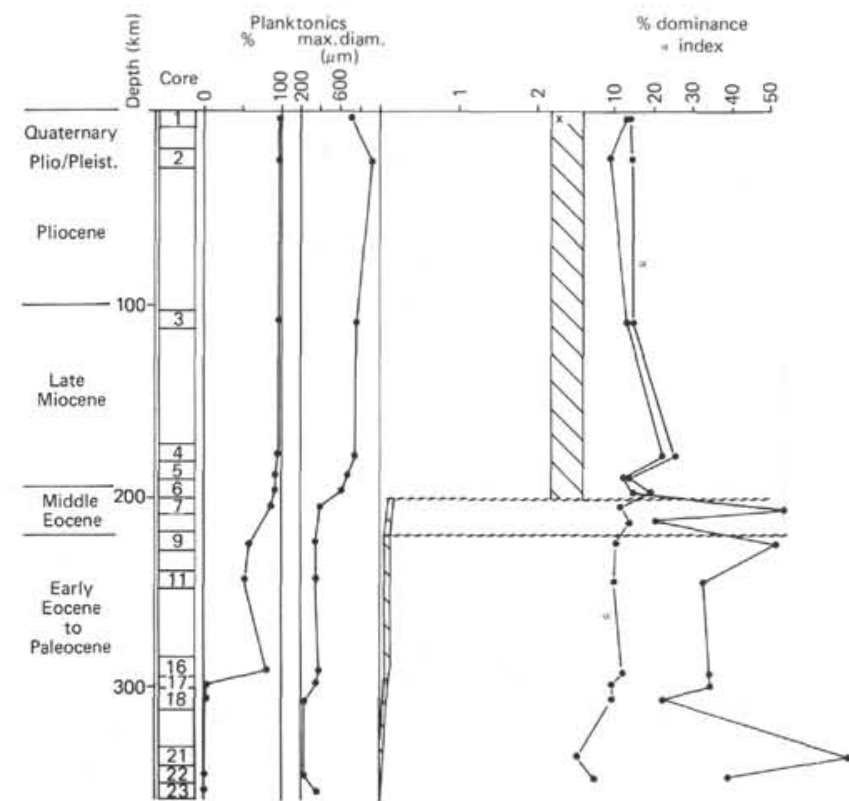

Figure 15. Summary log of Site 404 ( $R=$ rare foraminifers $)$.

\section{Site 405 (Figures 16 and 17)}

In general the recovery of benthic foraminifers from the Paleogene was poor due mainly to their low abundance and the small size of the samples. The oldest sample yielding an adequate fauna is Core 27 . The assemblage has high diversity $(\alpha=18)$. The dominant species include Nodosaria spp. and Cyclammina sp., with accessory Cibicidoides hercegovinensis, Globocassidulina subglobosa, Nonion cf. N. olssoni, Nuttallides truempyi, and Oridorsalis ecuadorensis. This is interpreted as epibathyal $(<1000 \mathrm{~m})$ because of the forms typical of deeper water (Stilostomella, Pleurostomella, Nuttallides truempyi - see Berggren and Aubert, 1976) only the former is common. The planktonic-benthic ratio is low for such a depth and this is not due to dissolution because juvenile planktonics are present in abundance. Two possible explanations are that conditions were unfavorable for planktonic forms at this time or that conditions were especially favorable for benthic production.

Core 8 yielded a similar assemblage of benthic forms dominated by Stilostomella spp., Dentalina sp., and Nodosaria spp. and with accessory Globocassidulina subglobosa, Nonion cf. N. olssoni, and Pleurostomella sp. This is likewise believed to represent epibathyal $(<1000 \mathrm{~m})$ depths. The planktonic:benthic ratio is high and the maximum diameter of the planktonic individuals is high for Eocene assemblages.

These assemblages include forms likely to have been derived from shallower water: Anomalinoides howelli, $A$. nobilis, Pulsiphonina prima, and Alabamina wilcoxensis.

\section{Site 406 (Figures 18 and 19)}

Only one core yielded an adequate assemblage (Core 42). The dominant species is Stilostomella spp., with accessory Gyroidinoides complanata, Gyroidinoides sp., Nuttallides truempyi, and Siphotextularia sp. The diversity is high. This is interpreted as epibathyal $(\sim 1000 \mathrm{~m})$.

The planktonic:benthic ratio of this core is lower than that of the other Paleogene cores, and this is partly why an assemblage count was possible.

\section{Discussion}

Paleogene benthic assemblages have been described from the North Atlantic by Berggren (1972a, b). Further details of the faunas from Rockall Bank and Hatton-Rockall Basin have been provided by Berggren (1974) and Berggren and Aubert (1976). Figure 20 shows diagrammatically the stratigraphic extent of the deposits at Sites 116 and 117 and also at Sites 403 to 406 . It shows that there is only partial

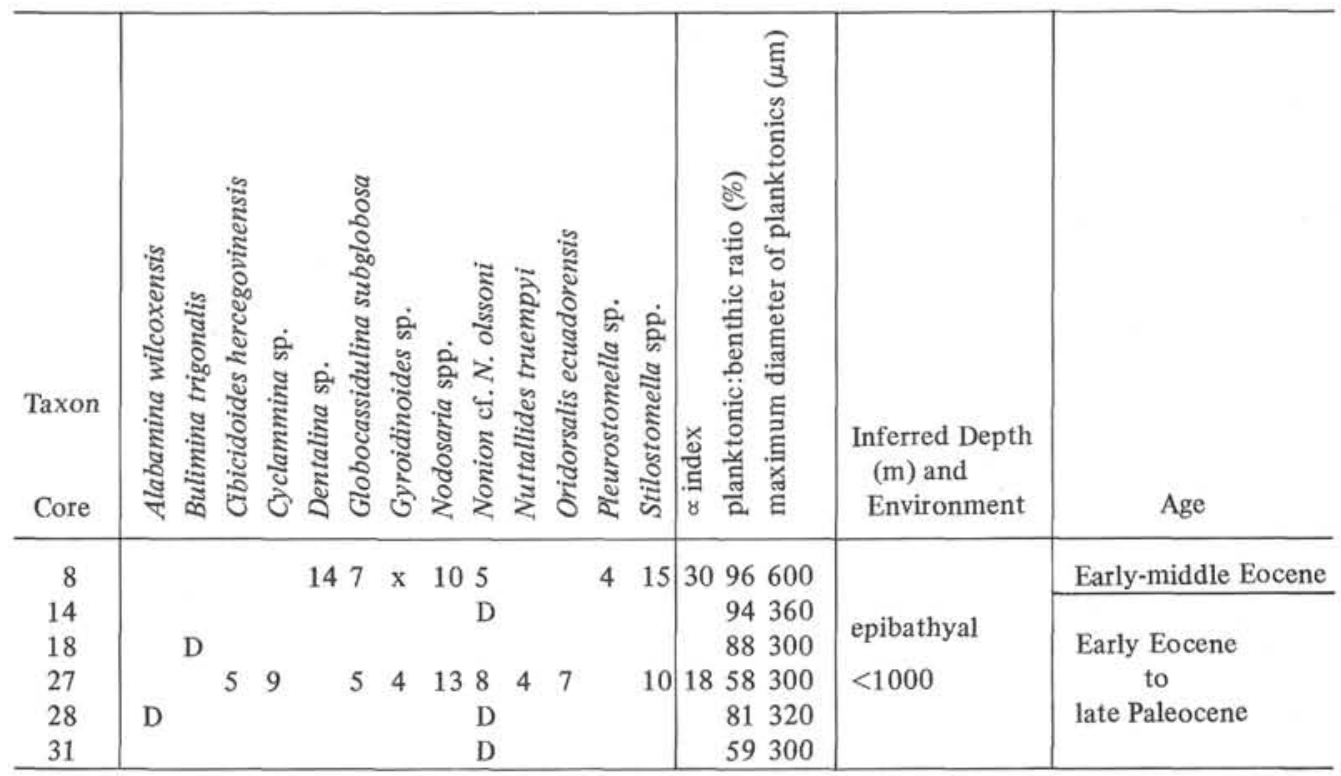

Figure 16. Occurrence of benthic foraminifers ( $>4 \%$ ) in the Paleogene at Site 405 values in $\%, x=\langle 4 \%$; Cores 12, 16, and 25 yielded few benthic forms; Cores 14, 18, 28, and 31 yielded $<100$ benthic forms, and $D=$ dominant species in these assemblages). 


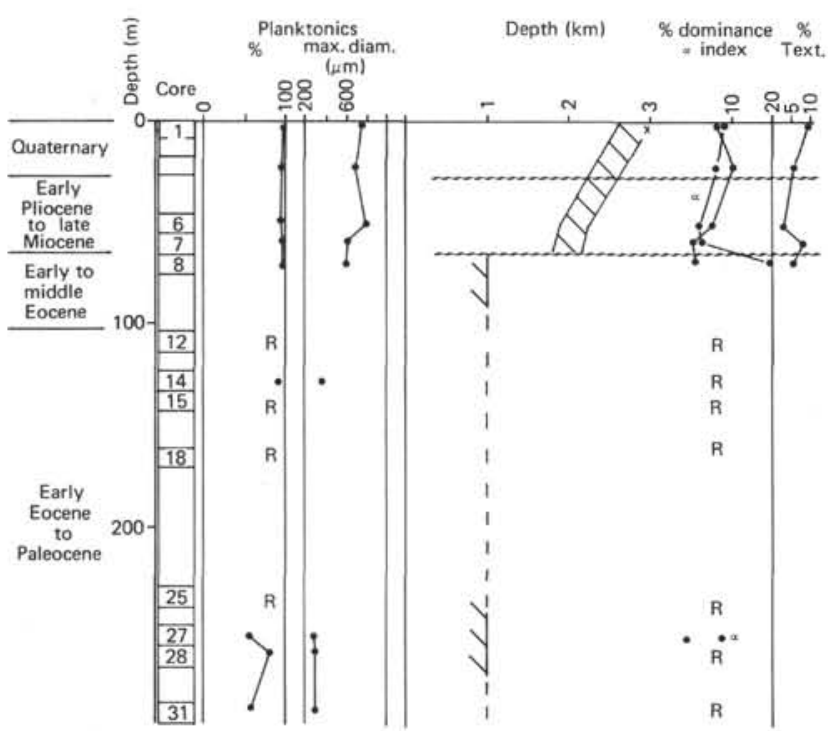

Figure 17. Summary log of Site 405 ( $R=$ rare foraminifers $)$.

overlap in time between the holes of Leg 12 and those of Leg 48. There are also facies differences between different sites.

Sites 403 and 404 were drilled close to one another and between them they provide a record of most of the Eocene. At Site 403 deposition commenced in mid to inner shelf depths $(<100 \mathrm{~m})$ in waters of normal salinity. A shallowing took place to a depth of $<10$ meters on the inner shelf close to a river as shown by brackish elements in the fauna. Thereafter, the water deepened to mid-inner shelf $(<100 \mathrm{~m})$ and normal marine conditions prevailed. In the middle Eocene it deepened to outer shelf then upper slope $(\sim 250 \mathrm{~m})$ and finally to $\sim 600$ meters in late Eocene-Oligocene times.

Thus, with the exception of the early Eocene shallowing (Core 34) subsidence exceeded the rate of sedimentation.
At Site 404 deposition started in depths of $<10$ meters, initially normal marine and then brackish, and this was followed by normal marine conditions with a slow increase in water depth to 75 to 150 meters in the early Eocene and 100 to 180 meters in the middle Eocene.

The inner shelf assemblages recorded here are quite differrent from those recorded by Berggren (1974) as faunal assemblage 1 from Site 117; none of the characteristic species listed by Berggren are present at Sites 403 and 404 . Some of the species present are found in the Hampshire Basin (England) and the Paris Basin (France) (see Murray and Wright, 1974), but there are no great faunal similarities.

In a general sense there is similarity between the mid-shelf early Eocene assemblages and faunal assemblage 2 of Berggren (1974) in the presence of Osangularia expansa and Cibicidoides succedens but there are also many differences, especially the dominance of Anomalinoides howelli. There are also major differences with the early Eocene of the Hampshire and Paris basins (see Murray and Wright, 1974). Middle Eocene is not represented at Sites 116 and 117 but the assemblages recorded here from Site 404 have some similarity with Berggren's faunal assemblage 3 (presence of Oridorsalis ecuadorensis).

Sites 406 and 405 differ from Sites 403 and 404 in representing deeper water, epibathyal environments. They also differ from the late Eocene-Oligocene assemblages of Sites 116 and 117 in the nature of the dominant species. This may be partly due to age differences as well as differences of environment of accumulation.

\section{Neogene}

Sites 403 and 404 (Figures 13, 15, 21, and 22)

Inspection of Figures 21 and 22 reveals that 15 species which form $>4$ per cent of the assemblage are present at both sites. Among these are Pullenia bulloides, Planulina wuel-

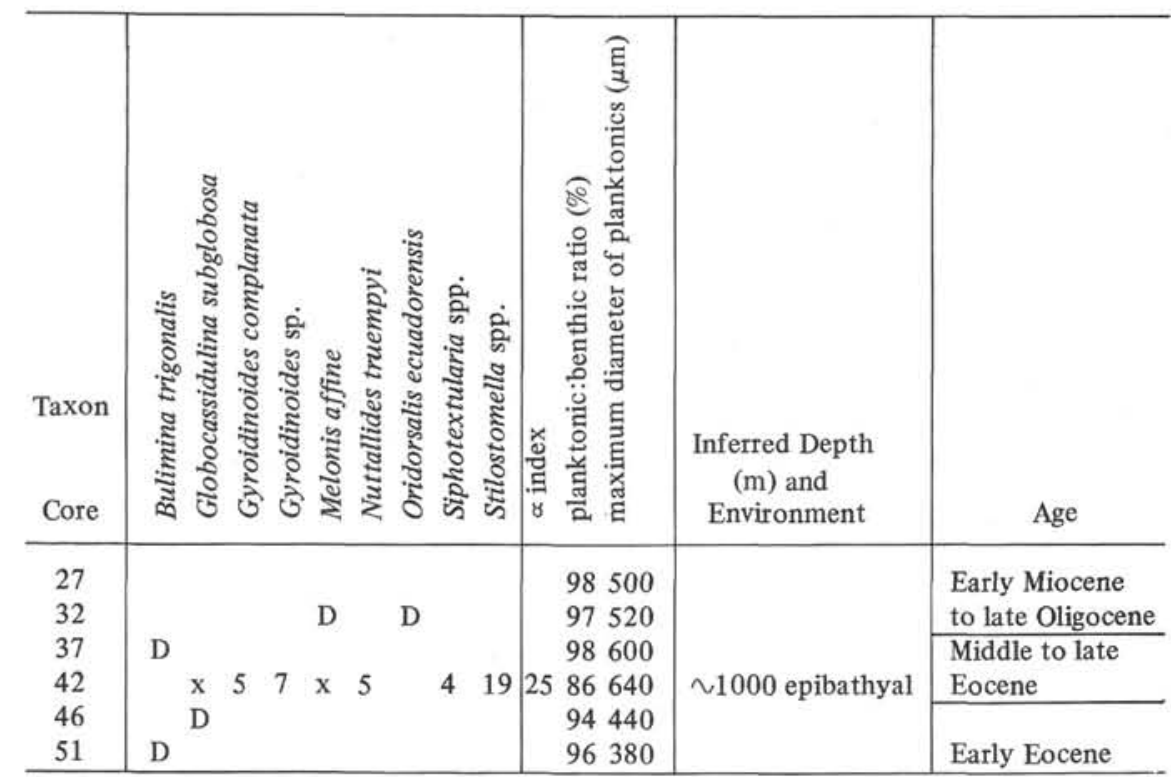

Figure 18. Occurrence of benthic foraminifers $(>4 \%)$ in the Paleogene at Site 406 (values in \%, $x=<4 \%$; Cores 27, 39, 37, 46, and 51 yielded small assemblages, $D=$ dominant species). 


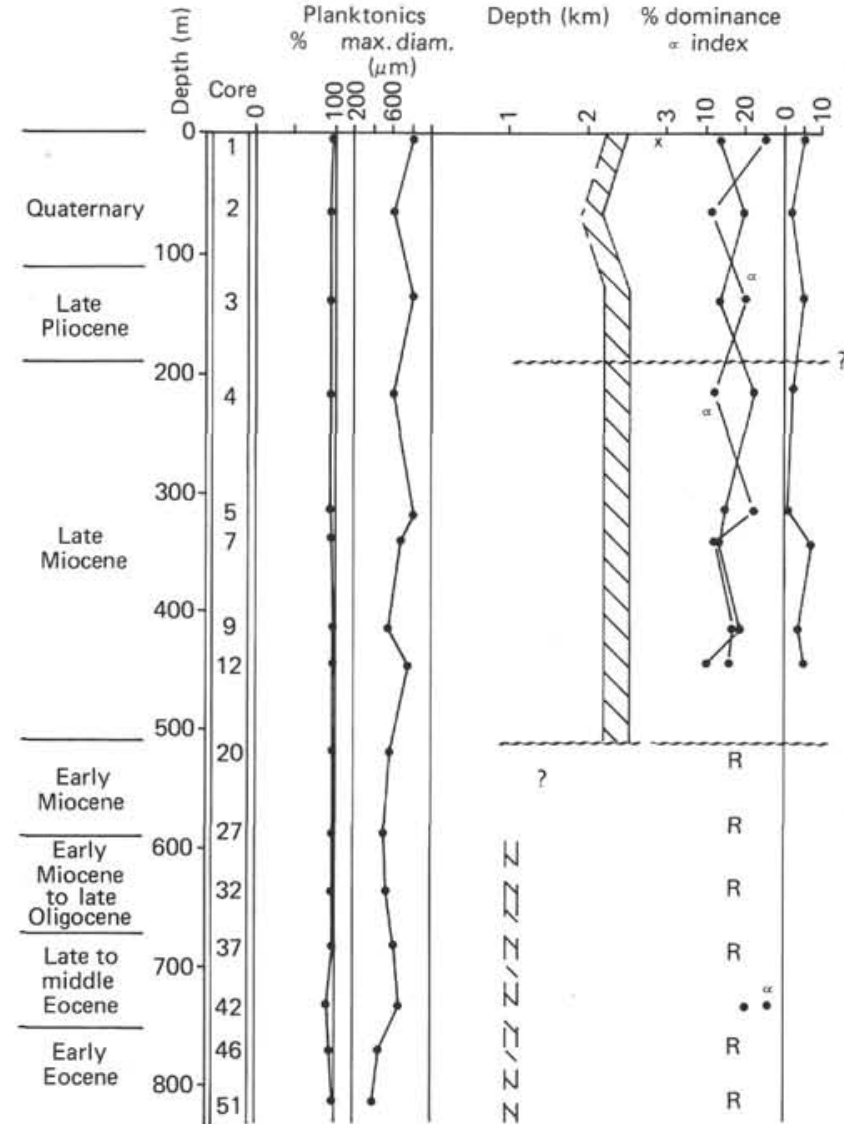

Figure 19. Summary log of Site $406(R=$ rare foraminifers $)$.

lerstorfi, and Oridorsalis umbonatus, all part of the Planulina wuellerstorfi fauna which, according to Brouwer (1973), extends from 1350 to 5084 meters. At these sites Bulimina striata and Uvigerina peregrina (lower depth limit $\sim 2200 \mathrm{~m}$ ) and Cibicidoides robertsonianus (upper depth limit $\sim 2600 \mathrm{~m}$ ) are generally absent or present only in very low abundance. Thus, the depth range may be in the range $\sim 2200$ (lower limit of the former) to $\sim 2600$ meters (upper limit of the latter). Some check is provided by the top cores as both holes are known to have been drilled in $\sim 2300$ meters of water. The whole of the late Miocene to Recent record suggests a similar depth of deposition.

Sites 405 and 406 (Figures 17, 19, 23, 24)

The Planulina wuellerstorfi fauna is present throughout the Neogene of Site 405. Uvigerina peregrina is a common species in Cores 7 and 6 (late Miocene-early Pliocene) which suggests a depth $<2260$ meters. Cibicidoides robertsonianus is absent here too, but appears in low abundance in Core 3 and in moderate abundance in Core 1 (Pleistocene). This may indicate a deepening to $>2600$ meters (the hole was drilled in $2958 \mathrm{~m}$ ). An upper depth limit of $\sim 1800$ meters in Cores 7 and 6 is suggested by the abundance of Textulariina (compare Figures 17 and 11).

The Pleistocene sample (Core 1) includes Rupertina stabilis, a species originally described from the "cold area", of the Faeroe Channel, at a depth of 1156 meters. This form lives attached to shells and rocks, and its presence in this

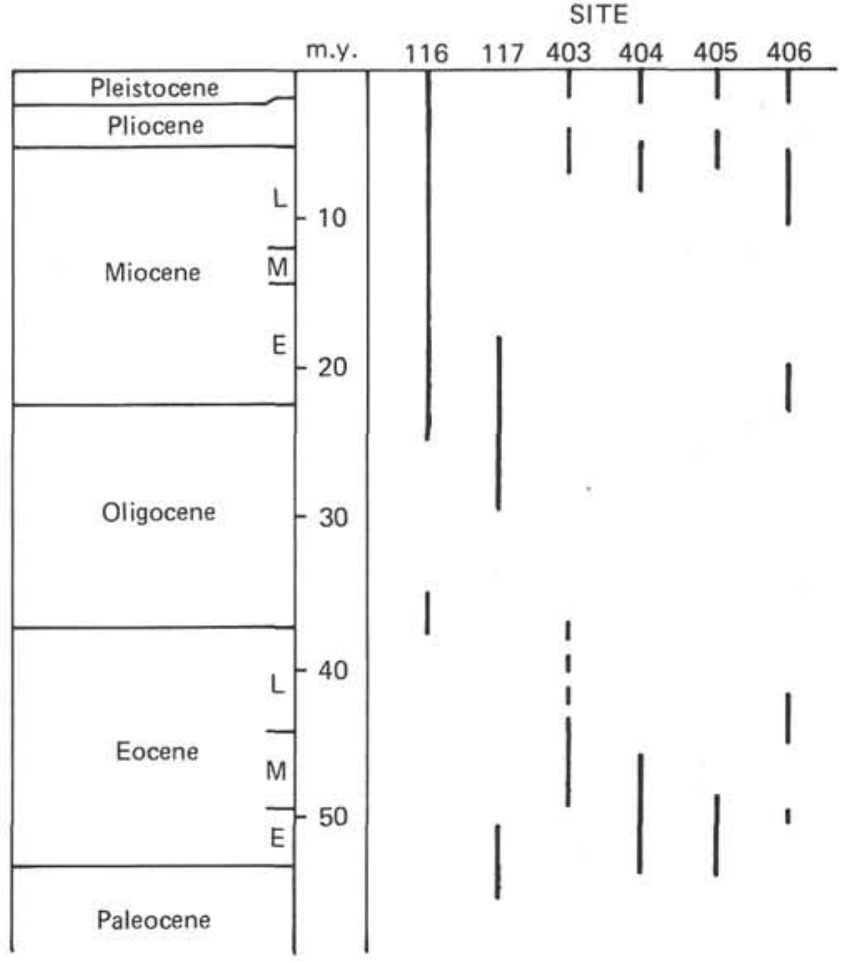

Figure 20. Stratigraphic extent of sediments at Sites 116, $117,403-406$.

sample indicates the nearby existence of such a firm substrate at the time of deposition.

The early Miocene sediments at Site 406 (Core 20) yielded only a small benthic assemblage from which little can be inferred. The remainder of the Neogene is characterized by the Planulina wuellerstorfi fauna. Bulimina striata is absent. Uvigerina peregrina is generally absent but makes up 10 per cent of the assemblage in Core 2. Cibicidoides robertsonianus is absent. The percentage of Textulariina is variable but reaches a maximum of 6.6 per cent.

With the exception of Core 2, depths of 2200 to 2500 meters are indicated by the above data. Core 2 indicates a depth of $<2200$ meters from the common $U$. peregrina. The hole was drilled in 2907 meters of water so the results from the foraminifers do not accord with the known depth at the top of the succession.

\section{Discussion}

All of the late Miocene to Pleistocene benthic assemblages have a modern appearance, being made up of species known to be living in the North Atlantic today. Berggren (1972b) suggested that the change to the modern fauna took place in the middle Miocene (not sampled here).

These Neogene assemblages are characterized by their very high diversity $(\alpha=11-25)$, moderate to low per cent faunal dominance (generally $<16 \%$, rarely up to $22 \%$ ), very low abundance of Miliolina (a few Pyrgo and Triloculina), low abundance of Textulariina $(<10 \%)$, and predominance of Rotaliina.

It has already been stressed that changes in depth are accompanied by changes in other environmental parameters. In view of the similarity of the Neogene assemblages to those 


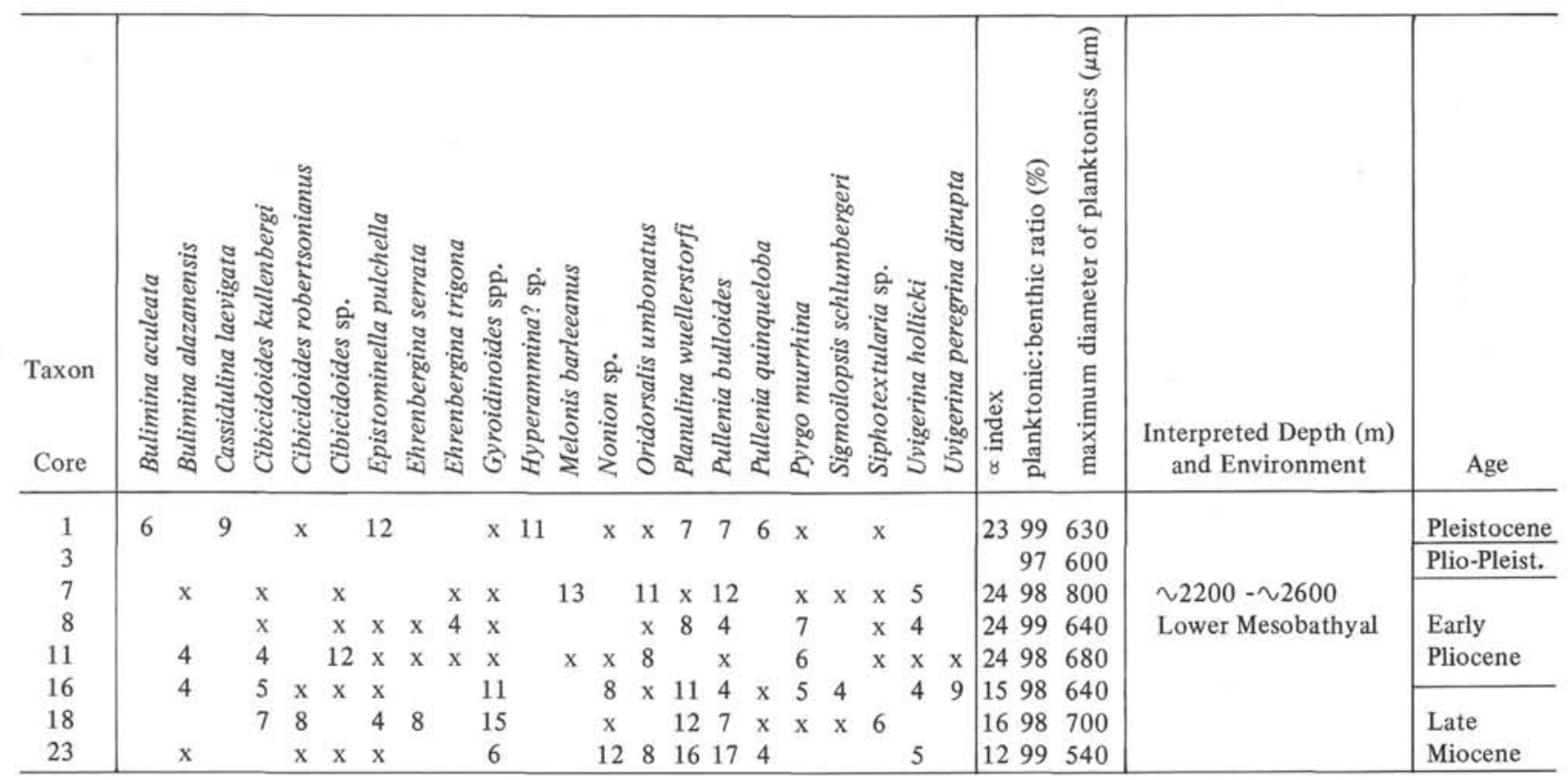

Figure 21. Occurrence of benthic foraminifers $(>4 \%)$ in the Neogene at Site 403 (values in $\% ; x=<4 \%$; core $3 y$ ielded only a small assemblage).

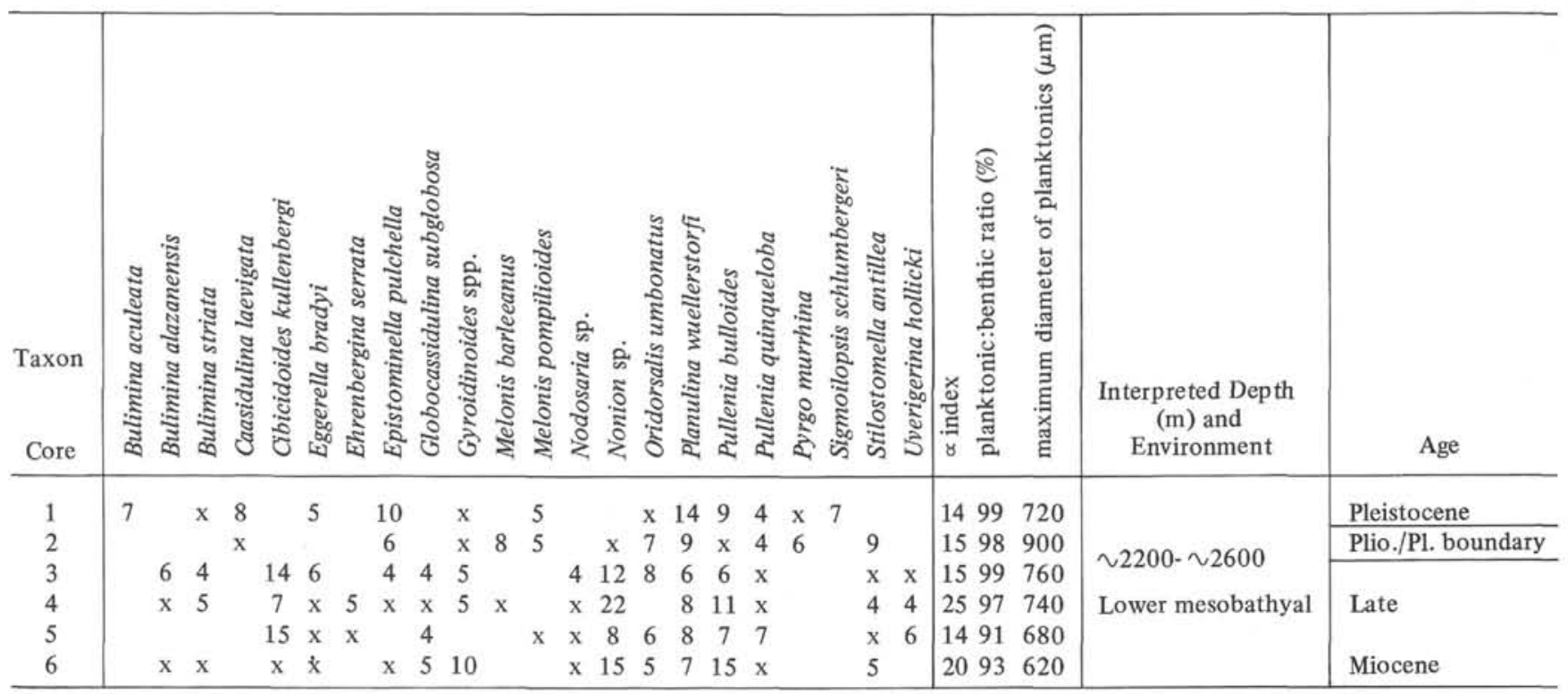

Figure 22. Occurrence of benthic foraminifers $(>4 \%$ ) in the Neogene at Site 404 (values in $\%, x=<4 \%$ ).

of the North Atlantic at present, it seems likely that Neogene temperature and salinity at depth were no more variable than at present.

Around much of the North Atlantic, submarine canyons are well developed and downslope transport of benthic foraminifers takes place (see Pujos-Lamy, 1973a, on the Bay of Biscay). No submarine canyons exist at present on Rockall Bank (Roberts, 1975) so downslope transport is low and this seems to have been the case throughout the Neogene.

\section{SUMMARY}

The rifted northwest margin of Rockall Plateau was the site of shallow water, continental shelf, deposition of sediments in the late Paleocene-early Eocene. More rapid subsidence took place during the middle Eocene giving water depths of $\sim 600$ meters in the late Eocene-early Oligocene (Site 403). Sediments representing most of the Oligocene to middle Miocene are absent. Late Miocene sedimentation was bathyal $(\sim 2200-\sim 2600 \mathrm{~m})$ and these deep water conditions have continued until the present day.

The basin south of Rockall Plateau adjacent to the transform fault was already $\sim 1000$ meters deep by the early Eocene and remained so until the late Eocene (Sites 405 and 406). There is then a break in the sedimentary record until the early Miocene (few benthic foraminifers) and a further break until the late Miocene. From this time until the present this 


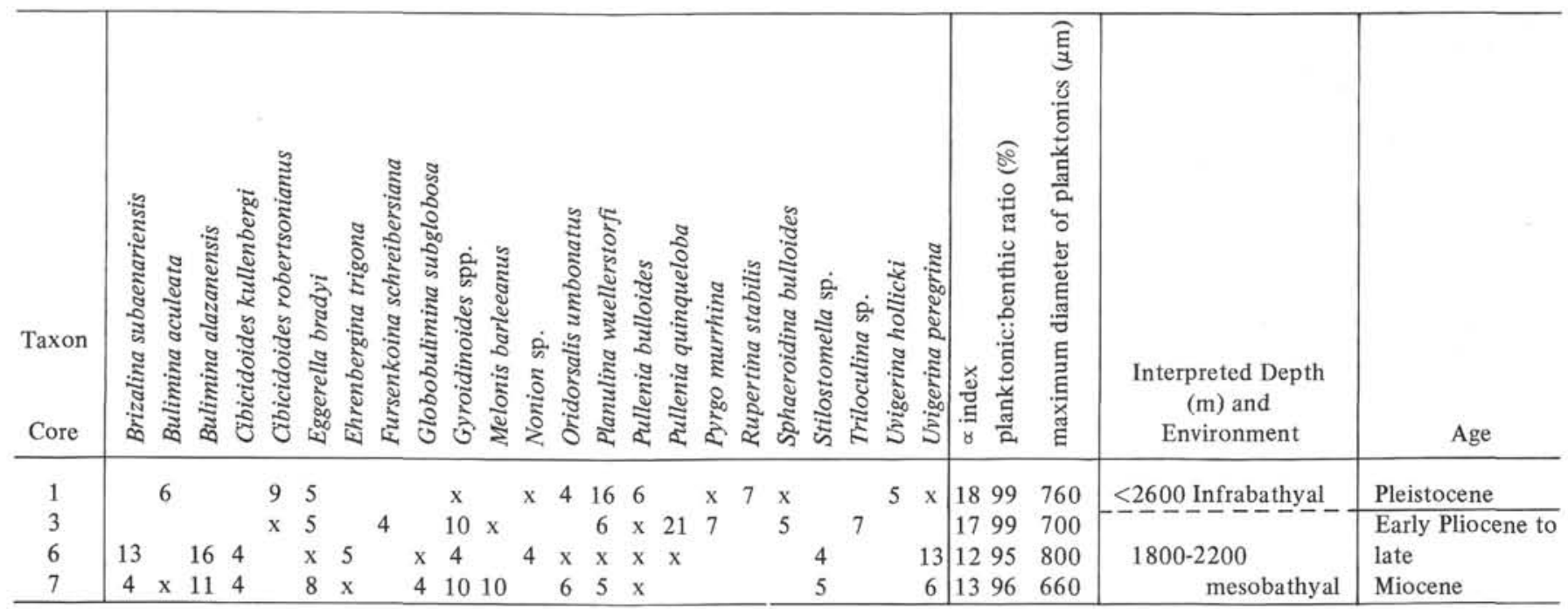

Figure 23. Occurrence of benthic foraminifers $>4 \%$ ) in the Neogene at Site 405.(values in $\%, x=<4 \%$ ).

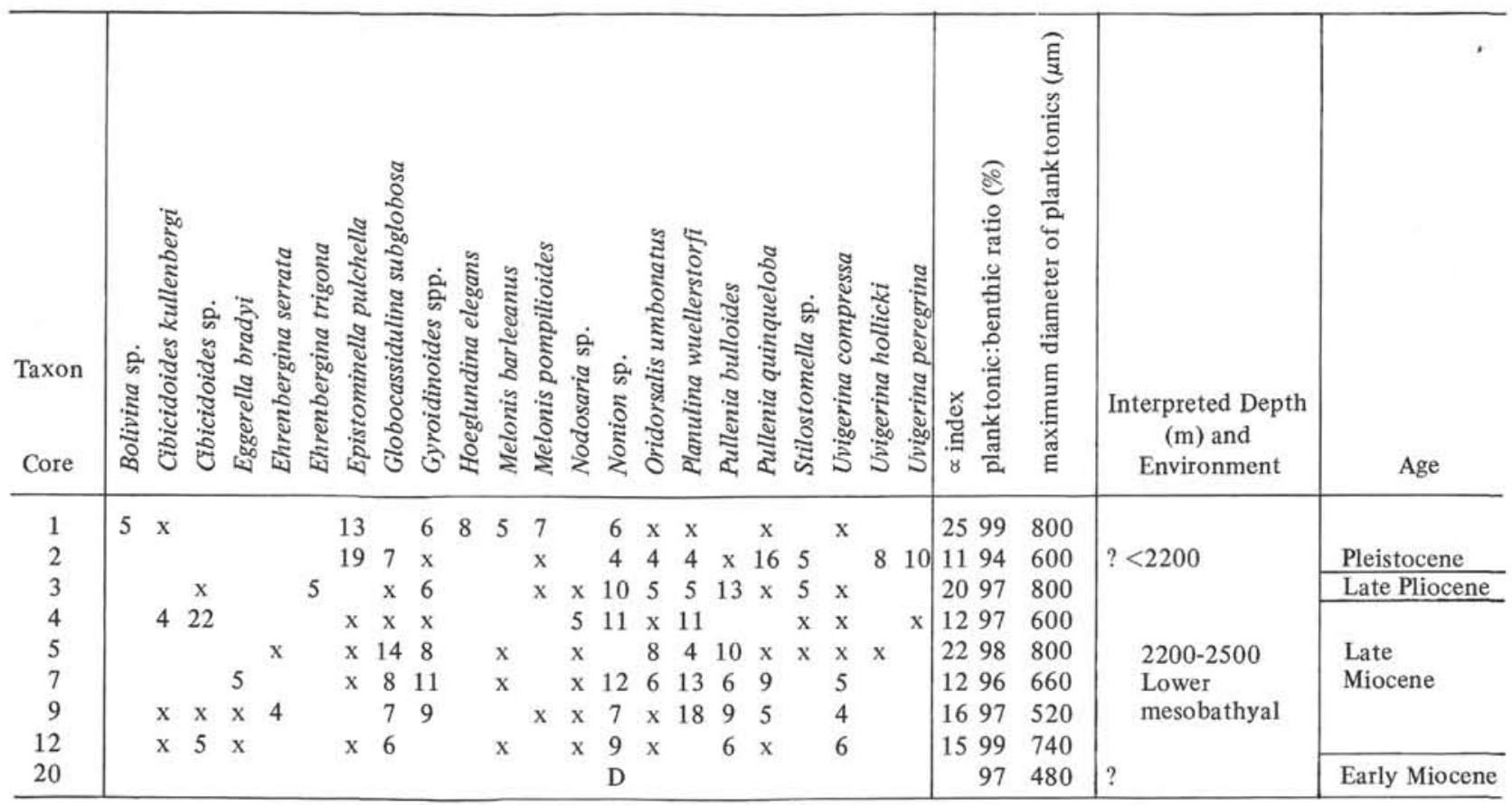

Figure 24. Occurrence of benthic foraminifers $>4 \%$ ) in the Neogene at Site 406 (values in $\%, x=<4 \% ; D=$ dominant species in a small assemblage).

area has been bathyal $(\sim 1800-\sim 3000 \mathrm{~m}$; note that the present water depth is $\sim 2950 \mathrm{~m}$ ).

The late Miocene benthic fauna is modern in aspect and it seems likely that the temperature and salinity conditions of the Miocene bathyal zone were no more variable than those today.

\section{ACKNOWLEDGMENTS}

I am grateful to Dr. J.R. Haynes, University College of Wales, for reading the manuscript and offering helpful comment, and to Mrs. G.C. Wright who typed it.

\section{REFERENCES}

Bandy, O.L., 1964. General correlation of foraminiferal structure with environment. In Imbric, J. and Newell, N. (Eds.), Approaches to Paleoecology: New York, J. Wiley, p. 75-90.

Bandy, O.L. and Chierici, M.A., 1966. Depth-temperature evaluation of selected California and Mediterranean bathyal foraminifera, Marine Geology, v. 4, p. 259-271.

Banner, F.T. and Blow, W.H., 1960. Some primary types of species belonging to the superfamily Globigerinaceae, Contributions from the Cushman Foundation for Foraminiferal Research, v. 11, p. 1-41. 
Belyaev, G.M., 1966. Hadal bottom fauna of the world ocean. Academy of Science, USSR, Institute of Oceanology. Translated by Zenkevich, L.A., 1972. Israel Program for Scientific Translation.

Berggren, W.A., 1972a. Sites 116 \& 117, Appendix D. In Laughton, A.S., Berggren, W.A., et al., Initial Reports of the Deep Sea Drilling Project, v. 12: Washington (U.S. Government Printing Office), 517-531.

, 1972b. Cenozoic biostratigraphy and paleobiogeography of the North Atlantic. In Laughton, A.S., Berggren, W.A., et al., Initial Reports of the Deep Sea Drilling Project, v. 12: Washington (U.S. Government Printing Office), p. 9651001 .

, 1974. Late Paleocene-early Eocene benthonic foraminiferal biostratigraphy and paleoecology of Rockall Bank, Micropaleontology, v. 20, p. 426-428.

Berggren, W.A. and Aubert, J., 1976. Late Paleogene (late Eocene and Oligocene) benthonic foraminiferal biostratigraphy and paleobathymetry of Rockall Bank and Hatton-Rockall Basin. Micropaleontology, v. 22, p. 307-326.

Blow, W.H., 1969. Late Middle Eocene to Recent planktonic foraminiferal biostratigraphy, Proceedings First International Conference on Planktonic Microfossils, v. 1., p. 199-422.

Boltovskoy, E. and Wright, R., 1976. Recent foraminifera: The Hague (Junk), p. 515.

Brady, H.B., 1884. Report on the foraminifera dredged by HMS Challenger during the years 1973-1876,Report on the Scientific Results of the Exploring Voyage of HMS Challenger, 1873-7. v. 9, p. 1-814.

Brouwer, J. 1973. Foraminiferal faunas from deep-sea sediments in the Gulf of Guinea, Verhandelingen van het Konink. Nederlandsch Geologisch-Mijnbouwkundig genootschap, v. 30, p. 19-55.

Caralp, M., Lamy, A., and Pujos, M., 1970. Contribution a la connaissance de la distribution bathymétrique des Foraminifères dans le Golfe de Gascogne, Revista Espanola de Micropaleontologia, v. 2, p. 55-84.

Cushman, J.A., 1918-1931. The foraminifera of the Atlantic Ocean, Bulletin of the United States National Museum, no. 104.

Daniels, C.H. von and Spiegler, D., 1974. Bolboforma n. gen. (Protozoa?) — eine neue stratigraphisch wichtige Gattung aus dem Oligozän/Miozän Nordwestdeutschlands, Paläontologische Zeitschrift, v. 48, p. 57-76.

Fisher, R.A., Corbet, A.S., and Williams, C.B., 1943. The relationship between the number of species and the number of individuals in a random sample of an animal population, Journal of Animal Ecology, v. 12, p. 42-58.

Loeblich, A.R., Tappan, H., Beckmann, J.P., Bolli, H.M., Galitelli, E.M., and Troelsen, J.C., 1957. Studies in foraminifera, United States National Museum Bulletin 215, p. 1-323.

Murray, J.W., 1971. An Atlas of British Recent Foraminiferids: London, (Heinemann Educational Books), p. 244.

1973. Distribution and ecology of living benthic foraminiferids: London, (Heinemann Educational Books), p. 288 .

, 1976a. Comparative studies of living and dead benthic foraminiferal distributions. In Hedley, R.H. and Adams, C.G. (Eds.), Foraminifera, v. 2, p. 45-109.

,1976b. A method of determining proximity of marginal seas to an ocean, Marine Geology, v. 22, p. 103-119.

Murray, J.W. and Wright, C.A., 1974. Palaeogene Foraminiferida \& palaeoecology, Hampshire \& Paris Basins \& the English Channel, Special Papers in Palaeontology, no. 14, p. 1-129.

Poore, R.Z. and Berggren, W.A., 1975. Late Cenozoic planktonic foraminiferal biostratigraphy and paleoclimatology of HattonRockall Basin: DSDP site 116, Journal of Foraminiferal Research, v. 5 , p. $270-293$.
Postuma, J.A., 1971. Manual of planktonic foraminifera: Amsterdam (Elsevier).

Pujos-Lamy, A., 1972. Les foraminiferes agglutinants du Quaternaire récent dans le domaine profond du Golfe de Gascogne, Boreas, v. 1, p. $185-198$.

, 1973a. Répartition bathymétrique des Foraminifères benthiques profonds du Golfe de Gascogne. Comparaison avec d'autres aires océaniques, Revista Espanola de Micropaleontologia, v. 5, p. 213-234.

, 1973b. Le déplacement des faunes de Foraminifères benthiques actuels sur la pente continentale et dans la plaine abyssale du Golfe de Gascogne, Bulletin de la Société géologique de la France, v. 15 , p. $392-400$.

Roberts, D.G. 1975. Marine geology of the Rockall Plateau and Trough, Philosophical Transactions of the Royal Society, v. 278, p. 447-509.

Rögl, F. 1976. The occurrence of Bolboforma, a probable algal cyst, in the Antarctic Miocene of DSDP Leg 35. In Hollister, C.D., Craddock, C., et al., Initial Reports of the Deep Sea Drilling Project, v. 35, Washington (U.S. Government Printing Office), p. 713-719.

Schnitker, D., 1974. West Atlantic Abyssal circulation during the past 120,000 years, Nature, v. 248, p. 385-387.

Seiler, W.C., 1975. Tiefenverteilung benthischer Foraminiferen am portugiesischen Kontinentalhang. "Meteor' Forsch.Ergebnisse, Reihe C., v. 23, p. 47-94.

Stainforth, R.H., Lamb, J.L., Luterbacher, H., Beard, J.H., and Jeffords, R.M., 1975. Cenozoic planktonic foraminiferal zonation and characteristics of index forms, University of Kansas Paleontological Contributions, Article 62, p. 1-425.

Streeter, S.S., 1973. Bottom water and benthonic Foraminifera in the North Atlantic-Glacial-Interglacial contrast, Quaternary Res., v. 3, p. 131-141.

Walton, W.R., 1964. Recent foraminiferal ecology and paleoecology. In Imbrie, J. and Newell, N. (Eds.), Approaches to Paleoecology: New York, (J. Wiley), p. 151-237.

\section{APPENDIX: FAUNAL REFERENCE LIST}

\section{Paleogene Planktonic Foraminifers}

Catapsydrax dissimilis $($ Cushman \& Bermudez $)=$ Globigerina dissimilis Cushman and Bermudez, 1937

Globigerapsis index $($ Finlay) $=$ Globigerinoides index Finlay, 1939

Globigerina boweri Bolli, 1957

Globigerina linaperta Finlay, 1939, group sensu Stainforth et al., 1975

Globigerina triangularis White, 1928

Globigerina cf. G. yeguaensis Weinzierl and Applin, 1929

Globigerinita unicava (Bolli, Loeblich, and Tappan) primitiva Blow \& Banner, 1962

Globorotalia bullbrooki Bolli, 1957

Globorotalia esnaensis $($ LeRoy) = Globigerina esnaensis LeRoy, 1953 Globorotalia pentacamerata Subbotina, 1947

Pseudohastigerina wilcoxensis $($ Cushman and Ponton $)=$ Nonion wilcoxensis Cushman and Ponton, 1932

Truncorotaloides rohri Brönnimann and Bermudez, 1953

\section{Paleogene Benthic Foraminifers}

Alabamina cf. A. obtusa (Burrows and Holland) = Pulvinulina exigua (Brady) var. obtusa Burrows and Holland, 1897

Alabamina wilcoxensis Toulmin, 1940

Alabaminoides howelli $($ Toulmin) $=$ Cibicides howelli Toulmin, 1941

Anomalinoides nobilis Brotzen, 1948

Bulimina trigonalis Ten Dam, 1944

Cancris auriculatus (Fichtel and Moll) primitivus Cushman and Todd, 1942

Cibicidina cf. C. walli Bandy, 1949

Cibicidoides alleni (Plummer) = Truncatulina alleni Plummer, 1927

Elphidium hiltermanni Hagn, 1952

Epistominella vitrea Parker, 1953

Florilus elongatum (d'Orbigny) = Nonionina elongata d'Orbigny, 1826 
Globocassidulina subglobosa $($ Brady) = Cassidulina subglobosa Brady, 1881

Gyroidina angustiumbilicata Ten Dam, 1944

Gyroidina neosoldanii Brotzen, 1936

Gyroidinoides complanata (Cushman and Stainforth) = Gyroidina com planata Cushman and Stainforth, 1945

Melonis affine (Reuss) = Nonion affinis Reuss, 1851

Nonion cf. N. olssoni (Berry) $=$ Nonion olssoni Berry, 1928

Nuttallides truempyi $($ Nuttall $)=$ Eponides truempyi Nuttall, 1930

Oridorsalis ecuadorensis (Galloway and Morrey) = Rotalia ecuadorensis Galloway and Morrey, 1929

Osangularia expansa (Toulmin) = Parrella expansa Toulmin, 1941

Pararotalia calvezae Loeblich and Tappan, 1957

Pulsiphonina prima (Plummer) = Siphonina prima Plummer, 1927

Spiroplectammina spectabilis (Grzybowski) = Spiroplecta spectabilis Gryzbowski, 1898

Turrilina brevispira Ten Dam, 1944

\section{Neogene Planktonic Foraminifers}

Biorbulina bilobata (d'Orb) = Globigerina bilobata d'Orbigny, 1846 Globigerina apertura Cushman, 1918

Globigerina bulloides d'Orbigny, 1826

Globigerina falconensis Blow, 1959

Globigerina nepenthes Todd, 1957

Globigerina parabulloides Blow, 1959

Globigerina praebulloides Blow, 1959, emend, Banner and Blow, 1962

Globigerina quinqueloba Natland egelida Cifelli and Smith, 1970

Globigerina venezuelana Hedberg, 1937

Globigerinoides quadrilobatus (d'Orbigny) = Globigerina quadrilobata d'Orbigny, 1846 (see Banner and Blow, 1960)

Globigerinoides quadrilobatus (d'Orb.) immaturus LeRoy, $1939=$ Globigerinoides sacculiferus (Brady immaturus LeRoy, 1939

Globigerinoides sicanicus de Stefani, 1950

Globoquadrina altispira (Cushman and Jarvis) = Globigerina altispira Cushman and Jarvis, 1936

Globoquadrina dehiscens (Chapman, Parr, and Collins) = Globorotalia dehiscens Chapman, Parr, and Collins, 1934.

Globorotalia acostaensis Blow, 1959

Globorotalia conoidea Walters = Globorotalia miozea Finlay conoidea Walters, 1965

Globorotalia continuosa Blow, 1959

Globorotalia crassaformis (Galloway and Wissler) = Globigerina crassaformis Galloway and Wissler, 1940

Globorotalia crassaformis (Galloway and Wissler) ronda Blow, 1969

Globorotalia hirsuta (d'Orb.) = Rotalina hirsuta d'Orbigny, 1839

Globorotalia inflata d'Orbigny, 1839

Globorotalia merotumida Blow and Banner, 1965

Globorotalia plesiotumida Blow and Banner = Globorotalia (Globototalia) tumida (Brady) plesiotumida Blow and Banner, 1965

Globorotalia pseudomiocenica Bolli and Bermudez, 1965

Globorotalia puncticulata (Deshayes) = Globigerina puncticulata " d'Orbigny" nobis Deshayes, 1832

Globorotalia scitula (Brady) = Pulvinulina scitula Brady, 1882

Globorotalia scitula (Brady) praescitula Blow, 1959
Globorotalia siakensis LeRoy, 1939

Globorotalia tosaensis Takayanagi and Saito, 1962

Globorotalia truncatulinoides (d'Orb.) =? Rotalina truncatulinoides d'Orbigny, 1839

Hastigerina aequilateralis $($ Brady) $=$ Globigerina aequilateralis Brady, 1879

Neogloboquadrina atlantica $($ Berggren $)=$ Globigerina atlantica Berggren, 1972

Neogloboquadrina pachyderma $($ Ehrenberg) = Aristerospira pachyderma Ehrenberg, 1861

Orbulina suturalis Brönnimann, emend. Blow, 1956

Orbulina universa d'Orbigny, 1839

Praeorbulina glomerosa Blow circularis Blow, 1956

Sphaeroidinellopsis subdehiscens (Parker and Jones) subdehiscens (Blow) $=$ Sphaeroidinella subdehiscens (Parker and Jones) subdehiscens Blow, 1959

\section{Neogene Benthic Foraminifers}

Brizalina subaenariensis (Cushman) = Bolivina subaenariensis Cushman, 1922

Bulimina aculeata d'Orbigny, 1826

Bulimina alazanensis Cushman, 1927

Bulimina striata d'Orbigny, 1843

Cassidulina laevigata d'Orbigny, 1826

Cibicidoides kullenbergi (Parker) = Cibicides kullenbergi Parker, 1953

Cibicidoides robertsonianus $($ Brady) $=$ Truncatulina robertsoniana Brady, 1881

Eggerella bradyi (Cushman) = Verneuilina bradyi Cushman, 1911

Ehrenbergina serrata Reuss, 1850

Ehrenbergina trigona Göes, Ehrenbergina serrata Reuss trigona, 1896

Epistominella pulchella Husezima and Marnhasi, 1944

Fursenkoina schreibersiana $($ Czjzek) = Virgulina schreibersiana Czjzek, 1848

Globocassidulina subglobosa (Brady) = Cassidulina subglobosa Brady, 1881

Hoeglundina elegans (d'Orbigny) = Rotalia elegans d'Orbigny, 1826

Melonis barleeanus (Williamson) = Nonionina barleeana Williamson, 1858

Melonis pompilioides (Fichtel and Moll) $=$ Nautilus pompilioides Fichtel and Moll, 1798

Oridorsalis umbonatus (Reuss) = Rotalina umbonatus Reuss, 1851

Planulina wuellerstorfi (Schwager) = Anomalina wuellerstorfi Schwager, 1866

Pullenia bulloides (d'Orbigny) = Nonionina bulloides d'Orbigny, 1846

Pullenia quinqueloba (Reuss) = Nonionina quinqueloba Reuss, 1851

Pyrgo murrhina $($ Schwager $)=$ Biloculina murrhina Schwager, 1866

Rupertina stabilis (Wallich) = Rupertia stabilis Wallich, 1877

Sigmoilopsis schlumbergeri (Silvestri) = Sigmoilina schlumbergeri Silvestri, 1904

Sphaeroidina bulloides d'Orbigny, 1826

Stilostomella antilles (Cushman) = Nodosaria antillea Cushman, 1923

Uvigerina compressa Cushman, 1926

Uvigerina hollicki Thalmann, 1950

Uvigerina peregrina Cushman, 1923

Uvigerina peregrina Cushman dirupta Todd, 1948 